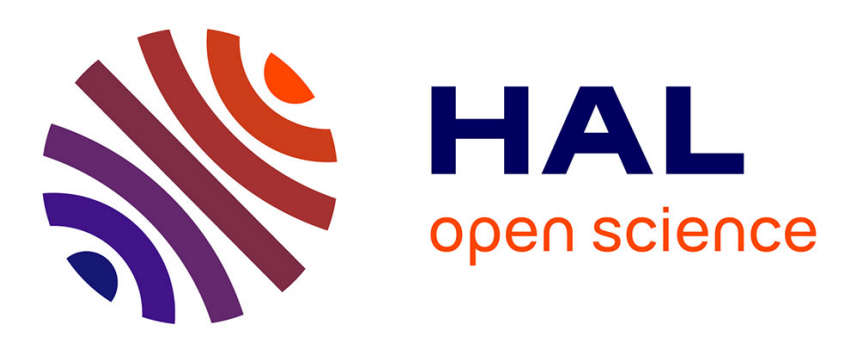

\title{
Ranking of mechanisms governing the phytoavailability of cadmium in agricultural soils using a mechanistic model
}

Zhongbing Lin, Andre Schneider, Thibault Sterckeman, Christophe Nguyen

\section{- To cite this version:}

Zhongbing Lin, Andre Schneider, Thibault Sterckeman, Christophe Nguyen. Ranking of mechanisms governing the phytoavailability of cadmium in agricultural soils using a mechanistic model. Plant and Soil, 2015, 399 (1), 10.1007/s11104-015-2663-6 . hal-01260301

\section{HAL Id: hal-01260301 https://hal.science/hal-01260301}

Submitted on 21 Jan 2016

HAL is a multi-disciplinary open access archive for the deposit and dissemination of scientific research documents, whether they are published or not. The documents may come from teaching and research institutions in France or abroad, or from public or private research centers.
L'archive ouverte pluridisciplinaire HAL, est destinée au dépôt et à la diffusion de documents scientifiques de niveau recherche, publiés ou non, émanant des établissements d'enseignement et de recherche français ou étrangers, des laboratoires publics ou privés. 


\title{
Ranking of mechanisms governing the phytoavailability of cadmium in agricultural soils using a mechanistic model
}

\author{
Zhongbing Lin • André Schneider • \\ Thibault Sterckeman • Christophe Nguyen
}

Received: 27 March 2015 / Accepted: 6 September 2015

(C) Springer International Publishing Switzerland 2015

\begin{abstract}
Aims The objective of this study was to rank the mechanisms influencing the phytoavailability of cadmium $(\mathrm{Cd})$ in agricultural soils.

Methods We developed a model that simulates the transport by diffusion and convection, the kinetics of sorption and complexation in solution and the root uptake of $\mathrm{Cd}$. The ranking of mechanisms was performed by simulating the $\mathrm{Cd}^{2+}$ uptake by $1 \mathrm{~cm}^{2}$ root for 30 days for French agricultural soil characteristics. Results The initial $\mathrm{Cd}^{2+}$ concentration was the most influential parameter followed by the soil buffer power for $\mathrm{Cd}^{2+}$ and by the soil water content and impedance
\end{abstract}

Responsible Editor: Fangjie Zhao.

Electronic supplementary material The online version of this article (doi:10.1007/s11104-015-2663-6) contains supplementary material, which is available to authorized users.

Z. Lin $(\bowtie) \cdot$ A. Schneider $\cdot$ C. Nguyen

INRA, UMR 1391 ISPA, 71, avenue Edouard Bourlaux,

F-33140 Villenave d'Ornon, France

e-mail: zblin@whu.edu.cn

A. Schneider

e-mail: Andre.Schneider@bordeaux.inra.fr

C. Nguyen

e-mail: Christophe.Nguyen@bordeaux.inra.fr

Z. Lin · A. Schneider · C. Nguyen

Bordeaux Sciences Agro, UMR 1391 ISPA, F-33170 Gradignan, France factor. The $\mathrm{Cd}^{2+}$ was generally strongly depleted at the root surface and the convection was almost negligible. In general, the $\mathrm{Cd}$ complex dissociation contributed little to the uptake due to a strong kinetics limitation. Conversely, the kinetics of sorption was little influential. Conclusions The initial concentration and diffusion of $\mathrm{Cd}^{2+}$ were the dominant processes governing the phytoavailability in non-polluted soils. A model considering only the transport and sorption of $\mathrm{Cd}^{2+}$ without kinetics would be adequate to predict the phytoavailability. The particular situations where these simplifications do not hold (relative error $>10 \%$ ) corresponded to a high supply of labile $\mathrm{Cd}$ complex toward plant roots.

\section{T. Sterckeman}

INRA, Laboratoire Sols et Environnement, UMR 1120, 2, avenue de la Forêt de Haye, TSA 40602, F54518 Vandoeuvre-lès-Nancy, France

e-mail: Thibault.Sterckeman@univ-lorraine.fr

\section{T. Sterckeman}

Laboratoire Sols et Environnement, UMR 1120, Université de Lorraine, 2, avenue de la Forêt de Haye, TSA 40602, F54518 Vandoeuvre-lès-Nancy, France

\section{Present Address:}

Z. Lin

School of Water Resources and Hydropower Engineering,

Wuhan University, No. 8, Donghu South Road,

Wuhan 430072, China 
Keywords Cd phytoavailability · Agricultural soils . Adsorption-desorption · Complexation · Dissolved organic matter

\section{Introduction}

Cadmium $(\mathrm{Cd})$ is a very toxic element, which naturally occurs in agricultural soils due to the parent material, sometimes in relatively high concentrations (Baize et al. 1999). Furthermore, this element is added to cultivated soils as a contaminant of agricultural inputs, in particular phosphate fertilizers and recycled wastes such as manure, compost, sewage sludges etc. Finally, Cd also enters cultivated soils as the results of atmospheric fallouts, from a natural origin or derived from human activities (Alloway and Steinnes 1999). Plant roots absorb $\mathrm{Cd}^{2+}$ from the soil solution (Cataldo et al. 1983; Redjala et al. 2009) and the contaminant is subsequently found in edible plant parts, which causes potential risk to humans due to the contamination of the food chain (Leblanc et al. 2004).

Plant roots mainly absorb $\mathrm{Cd}$ as free hydrated ion, $\mathrm{Cd}^{2+}$, at a rate which depends on its concentration at the root surface, according to a MichaelisMenten kinetics (Cataldo et al. 1983; Redjala et al. 2009). In agricultural soils, $\mathrm{Cd}^{2+}$ in solution is a minor fraction of the total soil $\mathrm{Cd}$. Indeed, a large fraction of the soil $\mathrm{Cd}$ is generally adsorbed onto the solid phase including clay and organic matter (Mesquita and Silva 2002; Sauvé et al. 2000a, b). In the soil solution, in addition to the free $\mathrm{Cd}^{2+}$ ion, $\mathrm{Cd}$ also exists as complexes, mainly formed with soluble organic ligands (Cornu et al. 2009, 2011). The concentration of $\mathrm{Cd}^{2+}$ at the root surface is governed by sorption and complexation reactions and by the transport of $\mathrm{Cd}$ toward the root surface by diffusion and mass flow (Schneider 2008; Sterckeman et al. 2004).

In literature, some empirical relationships were proposed to link the concentration of $\mathrm{Cd}$ in plants with the soil variables assumed to govern the phytoavailability of the metal, i.e., generally the concentration of the total or labile $\mathrm{Cd}$ as experimentally defined by specific extractions, the $\mathrm{pH}$, the soil organic matter and to a lesser extend the clay content (Hough et al. 2004; Tudoreanu and Phillips
2004). These correlation models can be good for some specific situations but due to the poor description of mechanisms, they are rarely reliable when extrapolating their predictions to contexts that are different from the ones used for their calibration. Therefore, mechanistic models appear as valuable alternative approach to predict $\mathrm{Cd}$ uptake more generically. A general model describing transport, sorption onto the solid phase and uptake by plant roots of one chemical species of nutrient has been developed in the 70's (Barber 1962; Barber and Cushman 1981; Nye and Marriott 1969). Specific improvements of the Barber's model have been performed to address specific questions. For instance, the modeling of the effect of root exudation/degradation on the solubilization of trace elements and phosphorus has been modeled with no kinetics (Ptashnyk et al. 2011; Schnepf et al. 2012) or with kinetics for dissolution but not for the complex dissociation (Seuntjens et al. 2004). Upscaling (Szegedi et al. 2008) or coupling with root architecture (Schnepf et al. 2012) have also been performed. The Barber's model was applied to the absorption of nutrients by branched systems including mycorrhiza (Schnepf et al. 2011) or roots with root hairs (Keyes et al. 2013).

Attempts have been made to extend the Barber's model to $\mathrm{Cd}$ uptake by crops but the predictions were not satisfactory (Mullins et al. 1986; Sterckeman et al. 2004). One possible reason for this may lie in the fact that the Barber's approach considers only one chemical species. Consequently, the model cannot correctly describe that $\mathrm{Cd}$ complexes formed with soluble organic ligands (Schneider 2008; Schneider and Nguyen 2011) can dissociate at the root surface and can buffer the concentration of $\mathrm{Cd}^{2+}$, which is the only species assumed to be absorbed by plant roots (Panfili et al. 2009). The buffering capacity of $\mathrm{Cd}$ complex depends on their lability (Degryse et al. 2006) and therefore the kinetics of complexation might be important to consider. The contribution of $\mathrm{Cd}$ complexes to the root uptake by considering the kinetics has been very recently carried out for an exogenous ligand added to polluted soil to enhance $\mathrm{Cd}$ extraction by plant roots in the context of phytoremediation (Lin et al. 2014). In the context of non-polluted agricultural soils where contrary to polluted soils, the $\mathrm{Cd}$ concentration is generally low 
(Baize et al. 2007), the buffering of $\mathrm{Cd}^{2+}$ at the root surface by $\mathrm{Cd}$ complexes formed with the soil dissolved organic matter may be significant.

The objectives of this study were 1) to use a Cd phytoavailability model that simulates the transport by diffusion and convection, the kinetics of sorption and of complexation in solution with the soil organic matter and the root uptake of the free metal, 2) to rank the mechanisms by a sensitivity analysis of the model including the interactions between the mechanisms and focusing on agricultural non-polluted soils, 3) to assess the relative importance of sorption and complexation on the $\mathrm{Cd}$ phytoavailability, 4) to examine if the description of kinetics for sorption and complexation is necessary or if equilibrium could be assumed.

\section{Materials and methods}

The phytoavailability model

Barber's model (Barber 1995; Barber and Cushman 1981) was one mechanistic model widely used to simulate major and trace element transport and uptake by plant root in soil. The governing equation of Barber's model in cylindrical geometry adapted to consider adsorption-desorption kinetics (Roose et al. 2001) are as follows:

$$
\begin{gathered}
\theta \frac{\partial C_{\mathrm{M}}}{\partial t}=\frac{1}{r} \frac{\partial}{\partial r}\left(r f \theta D_{\mathrm{M}} \frac{\partial C_{\mathrm{M}}}{\partial r}+r_{0} v_{0} C_{\mathrm{M}}\right)+\left(k_{d e s}^{\mathrm{M}} S_{\mathrm{M}}-\theta k_{a d s}^{\mathrm{M}} C_{\mathrm{M}}\right) \\
\frac{d S_{\mathrm{M}}}{d t}=\theta k_{a d s}^{\mathrm{M}} C_{\mathrm{M}}-k_{d e s}^{\mathrm{M}} S_{\mathrm{M}}
\end{gathered}
$$

In Eq. (1), $\theta$ is the soil volumetric water content $\left(\mathrm{cm}^{3}\right.$ soil water $\mathrm{cm}^{-3}$ soil), $C_{\mathrm{M}}$ is the metal concentration in soil solution ( $\mu \mathrm{mol} \mathrm{cm}{ }^{-3}$ solution), $t$ is the time (s), $r$ is the radial distance from the root axis $(\mathrm{cm}), f$ is the impedance factor $\left(\mathrm{cm}^{2}\right.$ soil $\mathrm{cm}^{-2}$ solution), $D_{\mathrm{M}}$ is the diffusion coefficient of the element in water $\left(\mathrm{cm}^{2} \mathrm{~s}^{-1}\right), r_{0}$ is the root radius $(\mathrm{cm}), v_{0}$ is the water flux at the root surface $\left(\mathrm{cm}^{3}\right.$ water $\mathrm{cm}^{-2}$ root surface area $\left.\mathrm{s}^{-1}\right), k_{a d s}^{\mathrm{M}}$ is the rate constant of adsorption from liquid phase onto solid phase for the metal $\left(\mathrm{s}^{-1}\right), k_{\mathrm{des}}^{\mathrm{M}}$ is the rate constant of desorption from solid phase to liquid phase for the metal $\left(\mathrm{s}^{-1}\right), S_{\mathrm{M}}$ is the concentration of the metal sorbed onto solid phase $\left(\mu \mathrm{mol} \mathrm{cm} \mathrm{cm}^{-3}\right.$ soil). The initial concentrations and boundary flux conditions of the above equations are as follows:

$$
\left\{\begin{array}{cccc}
C_{\mathrm{M}}=C_{\mathrm{M} 0} & S_{\mathrm{M}}=S_{\mathrm{M} 0} & r_{0} \leq r \leq r_{1} & t=0 \\
J_{\mathrm{M}}=-\frac{I_{\max } C_{\mathrm{M}}}{K_{\mathrm{m}}+C_{\mathrm{M}}} & & r=r_{0} & t \geq 0 \\
J_{\mathrm{M}}=0 & r=r_{1} & t \geq 0
\end{array}\right\}
$$

In Eq. (2), $C_{\mathrm{M} 0}$ is the initial metal concentration in the soil solution ( $\mu \mathrm{mol} \mathrm{cm}{ }^{-3}$ solution), $S_{\mathrm{M} 0}$ is the initial concentration of the metal sorbed onto solid phase ( $\mu \mathrm{mol} \mathrm{cm}{ }^{-3}$ soil), $I_{\max }$ is the maximum uptake rate of

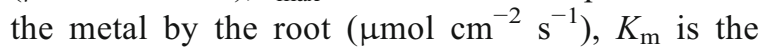
Michaelis affinity constant ( $\mu \mathrm{mol} \mathrm{cm}{ }^{-3}$ solution), i.e., the concentration of $\mathrm{M}$ in the soil solution when the uptake flux is half of $I_{\max }, r_{1}$ is the half distance between two root segments ( $\mathrm{cm}$ soil).

Barber's approach considers only one chemical species in the soil solution. Therefore, to study $\mathrm{Cd}$ complexation, we consider three species: the free $\mathrm{Cd}^{2+}$ ion (M) assumed to be the only species absorbed by roots and which forms complex (ML) in the soil solution with an unique ligand (L), following the reaction:

$\mathrm{M}+\underset{k_{d}}{\stackrel{k_{\text {a(cond) }}}{\rightleftarrows}} \mathrm{ML}$

The ligand was assumed to be representative of the dissolved endogenous soil organic matter, the concentration of which is at steady-state in the bulk soil. Therefore, no production/degradation equations were considered. Root exudation was also not accounted for. This complexation can be described by the following kinetics equations (Degryse et al. 2006; Schneider 2008; Schneider and Nguyen 2011):

$$
\left\{\begin{array}{c}
\frac{d C_{\mathrm{M}}}{d t}=k_{d} C_{\mathrm{ML}}-k_{\mathrm{a}}^{\text {cond }} C_{\mathrm{M}} C_{\mathrm{L}} \\
\frac{d C_{\mathrm{L}}}{d t}=k_{d} C_{\mathrm{ML}}-k_{\mathrm{a}}^{\text {cond }} C_{\mathrm{M}} C_{\mathrm{L}} \\
\frac{d C_{\mathrm{ML}}}{d t}=k_{\mathrm{a}}^{\text {cond }} C_{\mathrm{M}} C_{\mathrm{L}}-k_{d} C_{\mathrm{ML}}
\end{array}\right\}
$$

In Eq. (4), $C_{\mathrm{M}}, C_{\mathrm{L}}$, and $C_{\mathrm{ML}}$ are the concentra-

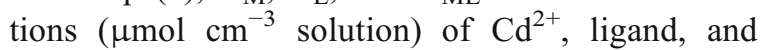
$\mathrm{Cd}$ complex in the soil solution, respectively, $k_{\mathrm{a}}^{\text {cond }}$ is the second-order conditional association rate constant $\left(\mathrm{cm}^{3}\right.$ solution $\left.\mu \mathrm{mol}^{-1} \mathrm{~s}^{-1}\right), k_{\mathrm{d}}$ is the 
first-order dissociation rate constant $\left(\mathrm{s}^{-1}\right)$. Completing Barber's model (Eq. 1) to account for the kinetics of complexation of $\mathrm{Cd}^{2+}$ with ligands in the soil solution (Eq. 4) and for the kinetics of sorption of the three species gives the following set of equations:

$$
\begin{aligned}
& \theta \frac{\partial C_{\mathrm{M}}}{\partial t}=\frac{1}{r} \frac{\partial}{\partial r}\left(r f \theta D_{\mathrm{M}} \frac{\partial C_{\mathrm{M}}}{\partial r}+r_{0} v_{0} C_{\mathrm{M}}\right)+\theta\left(k_{\mathrm{d}} C_{\mathrm{ML}}-k_{\mathrm{a}}^{\mathrm{cond}} C_{\mathrm{M}} C_{\mathrm{L}}\right)+\left(k_{\mathrm{des}}^{\mathrm{M}} S_{\mathrm{M}}-\theta k_{\mathrm{ads}}^{\mathrm{M}} C_{\mathrm{M}}\right) \\
& \theta \frac{\partial C_{\mathrm{L}}}{\partial t}=\frac{1}{r} \frac{\partial}{\partial r}\left(r f \theta D_{\mathrm{L}} \frac{\partial C_{\mathrm{L}}}{\partial r}+r_{0} v_{0} C_{\mathrm{L}}\right)+\theta\left(k_{\mathrm{d}} C_{\mathrm{ML}}-k_{\mathrm{a}}^{\text {cond }} C_{\mathrm{M}} C_{\mathrm{L}}\right)+\left(k_{\mathrm{des}}^{\mathrm{L}} S_{\mathrm{L}}-\theta k_{\mathrm{ads}}^{\mathrm{L}} C_{\mathrm{L}}\right) \\
& \theta \frac{\partial C_{\mathrm{ML}}}{\partial t}=\frac{1}{r} \frac{\partial}{\partial r}\left(r f \theta D_{\mathrm{ML}} \frac{\partial C_{\mathrm{ML}}}{\partial r}+r_{0} v_{0} C_{\mathrm{ML}}\right)+\theta\left(k_{\mathrm{a}}^{\mathrm{cond}} C_{\mathrm{M}} C_{\mathrm{L}}-k_{\mathrm{d}} C_{\mathrm{ML}}\right)+\left(k_{\mathrm{des}}^{\mathrm{ML}} S_{\mathrm{ML}}-\theta k_{\mathrm{ads}}^{\mathrm{ML}} C_{\mathrm{ML}}\right) \\
& \frac{d S_{\mathrm{M}}}{d t}=\theta k_{\mathrm{ads}}^{\mathrm{M}} C_{\mathrm{M}}-k_{\mathrm{des}}^{\mathrm{M}} S_{\mathrm{M}} \\
& \frac{d S_{\mathrm{L}}}{d t}=\theta k_{\mathrm{ads}}^{\mathrm{L}} C_{\mathrm{L}}-k_{\mathrm{des}}^{\mathrm{L}} S_{\mathrm{L}} \\
& \frac{d S_{\mathrm{ML}}}{d t}=\theta k_{\mathrm{ads}}^{\mathrm{ML}} C_{\mathrm{ML}}-k_{\mathrm{des}}^{\mathrm{ML}} S_{\mathrm{ML}}
\end{aligned}
$$

In Eq. (5), $D_{\mathrm{L}}$ and $D_{\mathrm{ML}}$ are the diffusion coefficients of the ligand and the Cd complex in water $\left(\mathrm{cm}^{2} \mathrm{~s}^{-1}\right)$, respectively, $k_{a d s}^{\mathrm{L}}$ and $k_{a d s}^{\mathrm{ML}}$ are the rate constants of adsorption from liquid phase onto solid phase for the ligand and the $\mathrm{Cd}$ complex $\left(\mathrm{s}^{-1}\right)$, respectively, $k_{d e s}^{\mathrm{L}}$ and $k_{\text {des }}^{\mathrm{ML}}$ are the rate constants of desorption from solid phase to liquid phase for the ligand and the $\mathrm{Cd}$ complex $\left(\mathrm{s}^{-1}\right)$, $S_{\mathrm{L}}$ and $S_{\mathrm{ML}}$ are the concentration of the ligand and the $\mathrm{Cd}$ complex sorbed onto solid phase ( $\mu \mathrm{mol} \mathrm{cm} \mathrm{cm}^{-3}$ soil), respectively. At the root surface, only $\mathrm{Cd}^{2+}$ is absorbed following Michaelis-Menten kinetics (Chen et al. 2008; Panfili et al. 2009) and so, the boundary fluxes are:

$$
\left\{\begin{array}{c}
J_{\mathrm{M}}=-\frac{I_{\max } C_{\mathrm{M}}}{K_{\mathrm{m}}+C_{\mathrm{M}}} \\
J_{L}=0 \\
J_{\mathrm{ML}}=0
\end{array}\right\} r=r_{0} \quad t \geq 0
$$

At the outer boundary of the domain, i.e., at the half distance between two root segments $\left(r=r_{1}\right)$, the fluxes for $\mathrm{Cd}^{2+}, \mathrm{L}$ and $\mathrm{CdL}$ are all set null. This enables representing the possible betweenroot competition for the uptake of $\mathrm{Cd}^{2+}$.

$$
\left\{\begin{array}{c}
J_{\mathrm{M}}=0 \\
J_{\mathrm{L}}=0 \\
J_{\mathrm{ML}}=0
\end{array}\right\} \quad r=r_{1} \quad t \geq 0
$$

And the initial conditions are:

$$
\left\{\begin{aligned}
C_{\mathrm{M}} & =C_{\mathrm{M} 0} \\
C_{\mathrm{L}} & =C_{\mathrm{L} 0} \\
C_{\mathrm{ML}} & =C_{\mathrm{ML} 0} \\
S_{\mathrm{M}} & =S_{\mathrm{M} 0} \\
S_{\mathrm{L}} & =S_{\mathrm{L} 0} \\
S_{\mathrm{ML}} & =S_{\mathrm{ML} 0}
\end{aligned}\right\} \quad r_{0} \leq r \leq r_{1} \quad t=0
$$

In Eq. (8), $C_{\mathrm{M} 0}, C_{\mathrm{L} 0}$, and $C_{\mathrm{ML} 0}$ are the initial concentrations of the free $\mathrm{Cd}^{2+}$, ligand, and complex in the soil solution ( $\mu \mathrm{mol} \mathrm{cm}{ }^{-3}$ solution); $S_{\mathrm{M} 0}, S_{\mathrm{L} 0}$, and $S_{\mathrm{ML} 0}$ are the initial concentrations of the sorbed $\mathrm{Cd}^{2+}$, ligand, and complex in soil ( $\mu \mathrm{mol} \mathrm{cm}{ }^{-3}$ soil). Then, the cumulative uptake of $\mathrm{Cd}^{2+}$ per unit root segment $\left(U_{\text {cum }}, \mu \mathrm{mol}\right.$ $\mathrm{cm}^{-2}$ ) for the duration $T(\mathrm{~s})$ is given by:

$U_{\text {cum }}=\int_{0}^{T} \frac{I_{\max } C_{\mathrm{M}}}{K_{\mathrm{m}}+C_{\mathrm{M}}} d t \quad r=r_{0}$

The effects of the different parameters on the phytoavailability of the metal in non-polluted agricultural soils were assessed by simulating the uptake of $\mathrm{Cd}^{2+}$ by $1 \mathrm{~cm}^{2}$ root for 30 days.

Model parameters domain for non-polluted agricultural soils

The initial concentrations of the free $\mathrm{Cd}^{2+}$ and of the complex as well as their buffer powers are not 
commonly determined in the literature and therefore, little data are available to help determining their relevant ranges of variations, which were therefore derived from parameters more commonly measured in the field.

Actual values of total $\mathrm{Cd}$ content (HF extraction; $\left.T M_{0}\right), p H$, and soil organic carbon (SOC) for French agricultural soils were derived from available national databases: RMQS (RMQS C 2013), BDETM (BDETM (C) 2013), and ASPITET (Baize et al. 2007). Extreme

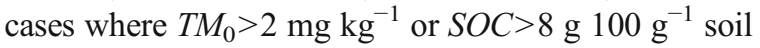
were discarded (less than $1 \%$ of the data). The resulting dataset had 8707 unique triplets $\left(T M_{0}, p H, S O C\right)$. The correlation coefficients between $p H$ and $T M_{0}$, and between $S O C$ and $T M_{0}$, are 0.30 and 0.39 , respectively.

We assumed that the kinetics of sorption for $\mathrm{Cd}^{2+}$, for the ligand and complex, and of complexation between $\mathrm{Cd}^{2+}$ and the ligand were at equilibrium at the beginning of simulations. The soil/solution partitioning coefficient for total $\mathrm{Cd}\left(K_{d}^{\mathrm{TOT}}, \mathrm{cm}^{3}\right.$ solution $\mathrm{g}^{-1}$ soil) was determined using the following statistical model (Degryse et al. 2009):

$\log _{10}\left(K_{\mathrm{d}}^{\mathrm{TOT}}\right)=-1.04+0.55 p H+0.70 \log _{10}($ SOC $)$

Then the initial concentration of total $\mathrm{Cd}$ in the soil solution $\left(C_{\mathrm{M}}^{\mathrm{TOTO}}, \mu \mathrm{mol} \mathrm{cm}{ }^{-3}\right.$ solution $)$ was calculated as follows:

$C_{\mathrm{M}}^{\mathrm{TOTO}}=\frac{T M_{0}}{m_{C d} K_{\mathrm{d}}^{\mathrm{TOT}}}$

Where, $m_{\mathrm{Cd}}$ is the atomic weight of $\mathrm{Cd}$ (112.411 $\mathrm{g} \mathrm{mol}^{-1}$ ).

In order to calculate the speciation of $\mathrm{Cd}$ in the soil solution, we assumed that $\mathrm{Cd}$ was complexed by the humic acids (HA) and fulvic acids (FA) of the dissolved organic carbon (DOC) with $\mathrm{H}$ and $\mathrm{Ca}$ being the competitor cations. The proportion of HA in DOC $\left(p c_{\mathrm{HA}}\right)$ was considered to depend on soil $\mathrm{pH}$. Data from You et al. (1999) were used to fit an empirical logistic model for the $p c_{\mathrm{HA}}$ as a function of soil $\mathrm{pH}$ with 1 as a maximum:

$p c_{\mathrm{HA}}=\frac{1}{1+9984 e^{-1.26 p H}}$

Based on Haynes (2005), the DOC concentration measured in the $2: 1\left(\mathrm{~V}: \mathrm{W} ; \mathrm{L} \mathrm{kg}^{-1}\right)$ soil extraction, i.e., $D O C_{2: 1}$, can be assumed to be a fraction of the total soil organic carbon. Then, the concentration of $D O C_{2: 1}(\mathrm{mg}$ $\mathrm{C} \mathrm{L}^{-1}$ solution) is calculated as:

$$
\begin{aligned}
D_{2: 1}\left(\mathrm{mg} \mathrm{L}^{-1}\right)= & 1000 \times \frac{\operatorname{SOC}(\%)}{100} \\
& \times \frac{F_{\mathrm{DOC} / \mathrm{SOC}}}{100} \times 1000 \times \frac{1}{2}
\end{aligned}
$$

Where, $F_{\mathrm{DOC} / \mathrm{SOC}}$ is the DOC:SOC ratio (g DOC $100 \mathrm{~g}^{-1}$ SOC) ranging from 0.05 to $0.4 \mathrm{~g} \mathrm{DOC}$ $100 \mathrm{~g}^{-1}$ SOC (Haynes 2005). Considering a linear sorption, the partitioning coefficient of DOC $\left(K_{\mathrm{d}}^{\mathrm{L}}\right)$ is given by (Ponizovsky et al. 2006):

$$
\begin{aligned}
& K_{\mathrm{d}}^{\mathrm{L}}\left(\mathrm{L} \text { solution kg }{ }^{-1} \text { soil }\right) \\
& =\frac{\operatorname{SOC}_{2: 1}^{\mathrm{SF}}\left(\mathrm{g} \mathrm{C} \mathrm{kg}^{-1} \text { soil }\right)}{D O C_{2: 1}\left(\mathrm{~g} \mathrm{C} \mathrm{L}^{-1} \text { solution }\right)} \\
& =\frac{S O C^{\mathrm{SF}}\left(\mathrm{g} \mathrm{C} \mathrm{kg}^{-1} \text { soil }\right)}{D O C\left(\mathrm{~g} \mathrm{C} \mathrm{L}^{-1} \text { solution }\right)}
\end{aligned}
$$

In Eq. (14), $S O C_{2: 1}^{\mathrm{SF}}$ is the concentration of soluble fraction of SOC sorbed onto the solid phase at equilibrium with the solution at the 2:1 liter:kilogram ratio, $S O C^{\mathrm{SF}}$ is the concentration of soluble fraction of SOC sorbed onto the solid phase at natural soil moisture condition. Considering mass conservation, the partitioning coefficient of DOC was used to calculate the DOC concentration at the soil water content:

$K_{\mathrm{d}}^{\mathrm{L}} D O C-K_{\mathrm{d}}^{\mathrm{L}} D O C_{2: 1}=D O C_{2: 1} \times 2-D O C \frac{\theta}{\rho}$

Rewriting the above equation we obtain:

$$
D O C\left(\mathrm{mg} \mathrm{L}^{-1}\right)=D O C_{2: 1} \frac{K_{\mathrm{d}}^{\mathrm{L}}+2}{K_{\mathrm{d}}^{\mathrm{L}}+\frac{\theta}{\rho}}
$$

In Eqs. (15-16), $\rho$ is the soil density $\left(\mathrm{g} \mathrm{cm}^{-3}\right)$, which ranged between 1.3 and $1.7 \mathrm{~g} \mathrm{~cm}^{-3}$ (Bruand et al. 2004). The soil volumetric water content $\theta$ was allowed to vary between 0.05 and $0.45 \mathrm{~cm}^{3}$ water $\mathrm{cm}^{-3}$ soil. Considering the different textures of the French agricultural soils, this corresponds to the wilting point and to the water holding capacity, respectively (Bruand et al. 2004).

The speciation calculations were done with Cheaqs Pro (Release P2013.2; http://www.cheaqs.eu/) with $C_{\mathrm{M}}^{\mathrm{TOT} 0}, \mathrm{pH}, \mathrm{Ca}$ concentration, DOC, $p c_{\mathrm{HA}}$ as input parameters. The $\mathrm{Ca}^{2+}$ concentration ranged from 0.1 to 
$10 \mathrm{mM}$ and the charges of $\mathrm{Ca}^{2+}$ were equilibrated with $\mathrm{NO}_{3}{ }^{-}$. In Cheaqs Pro, organic complexation is calculated by using WHAM VII (Tipping et al. 2011). The WHAM model implemented in Cheaqs Pro considers that a cation is associated to FA or HA by specific associations (with a stability constant corresponding to site affinity) to form mono, bi and tri dentate complexes, and by nonspecific associations (double diffusion layer DDL).

$C_{\mathrm{ML} 0}=\left[\begin{array}{l}\left(C d F A_{\text {mono }}+C d F A_{\mathrm{bi}}+C d F A_{\text {tri }}+C d F A D D L\right)+ \\ \left(C d H A_{\text {mono }}+C d H A_{\mathrm{bi}}+C d H A_{\text {tri }}+C d H A D D L\right)\end{array}\right] \times 1000$

In Eq. (17), $C d F A$ and $C d H A$ corresponds to mono, bi and tri dentates $\mathrm{Cd}$ complexes with FA and HA, respectively $\left(\mathrm{mol} \mathrm{L}^{-1}\right)$.

From the output of Cheaqs Pro, the site densities of FA and HA are $6.01 \mathrm{mmol} \mathrm{g}^{-1}$ FA and $3.60 \mathrm{mmol} \mathrm{g}^{-1}$ $\mathrm{HA}$, respectively. Then total ligand concentration can be calculated as follows:

$C_{\mathrm{L}}^{\mathrm{TOT} 0}=\left[6.01 \times 10^{-3}\left(1-p c_{\mathrm{HA}}\right)+3.60 \times 10^{-3} p c_{\mathrm{HA}}\right] D O C \times 1000$

And the initial concentrations of free ligand and $\mathrm{Cd}$ in soil solution can be calculated as follows:

$C_{\mathrm{L} 0}=C_{\mathrm{L}}^{\mathrm{TOT} 0}-C_{\mathrm{ML} 0}$

$C_{\mathrm{M} 0}=C_{\mathrm{M}}^{\mathrm{TOT} 0}-C_{\mathrm{ML} 0}$

With the assumption that the complexation kinetics is at equilibrium at the beginning of simulation, the second-order conditional association rate constant $k_{\mathrm{a}}^{\text {cond }}$ is given by the following formula:

$k_{\mathrm{a}}^{\text {cond }}=\frac{C_{\mathrm{ML} 0} k_{\mathrm{d}}}{C_{\mathrm{M} 0} C_{\mathrm{L} 0}}=\frac{\left(1-F_{\mathrm{M} 0}\right) k_{\mathrm{d}}}{F_{\mathrm{M} 0} C_{\mathrm{L} 0}}$

In Eq. (21), $F_{\mathrm{M} 0}$ is the initial free $\mathrm{Cd}^{2+}$ ion fraction in the soil solution. The range of the first-order dissociation rate constant for the complex $\left(k_{\mathrm{d}}\right)$ was set as $10^{-6}$ to $10^{-2} \mathrm{~s}^{-1}$ (Degryse et al. 2006; Schneider and Nguyen 2011).

The soil/solution partitioning coefficient of the total $\mathrm{Cd}\left(K_{\mathrm{d}}^{\mathrm{TOT}}\right)$ can be rewritten from the soil/solution partitioning coefficient of $\mathrm{Cd}^{2+}\left(K_{\mathrm{d}}^{\mathrm{M}}, \mathrm{cm}^{3}\right.$ solution $\mathrm{g}^{-1}$ soil) and of $\mathrm{CdL}\left(K_{\mathrm{d}}^{\mathrm{ML}}, \mathrm{cm}^{3}\right.$ solution $\mathrm{g}^{-1}$ soil $)$ as:

$$
\begin{aligned}
K_{\mathrm{d}}^{\mathrm{TOT}} & =\frac{K_{\mathrm{d}}^{\mathrm{M}} C_{\mathrm{M} 0}+K_{\mathrm{d}}^{\mathrm{ML}} C_{\mathrm{ML} 0}}{C_{\mathrm{M}}^{\mathrm{TOT} 0}} \\
& =F_{\mathrm{M} 0} K_{\mathrm{d}}^{\mathrm{M}}+\left(1-F_{\mathrm{M} 0}\right) K_{\mathrm{d}}^{\mathrm{ML}}
\end{aligned}
$$

Then the soil/solution partitioning coefficient of $\mathrm{Cd}^{2+}$ $\left(K_{\mathrm{d}}^{\mathrm{M}}\right)$ can be derived as follows:

$K_{\mathrm{d}}^{\mathrm{M}}=\frac{K_{\mathrm{d}}^{\mathrm{TOT}}-\left(1-F_{\mathrm{M} 0}\right) K_{\mathrm{d}}^{\mathrm{ML}}}{F_{\mathrm{M} 0}}$

The range of $K_{\mathrm{d}}^{\mathrm{L}}\left(1-50 \mathrm{~cm}^{3}\right.$ solution $\mathrm{g}^{-1}$ soil) was derived from values reported in the literature for the soil/solution partitioning coefficients of the soil organic matter (Ponizovsky et al. 2006; Yin et al. 2002; You et al. 1999). We assumed that the soil/solution partitioning coefficients of the ligand and the complex were the same in the model $\left(K_{\mathrm{d}}^{\mathrm{ML}}=K_{\mathrm{d}}^{\mathrm{L}}\right)$.

Then the soil buffer powers for $\mathrm{Cd}^{2+}$, for the ligand and the complex were calculated as follows (Barber 1995):

$\left\{\begin{array}{c}b_{\mathrm{M}}=\rho K_{\mathrm{d}}^{\mathrm{M}} \\ b_{\mathrm{L}}=\rho K_{\mathrm{d}}^{\mathrm{L}} \\ b_{\mathrm{ML}}=b_{\mathrm{L}}\end{array}\right\}$

For the desorption rate constant of $\mathrm{Cd}^{2+}\left(k_{\mathrm{des}}^{\mathrm{M}}\right)$, we defined the range of variation from literature values (Chaturvedi et al. 2006; Chen et al. 2006; Cornu et al. 2007; Ernstberger et al. 2002; Tsang et al. 2007): $10^{-6}$ to $5.5 \times 10^{-4} \mathrm{~s}^{-1}$. This range was also chosen for the desorption rate constant of the ligand and of the complex $\left(k_{\mathrm{des}}^{\mathrm{L}}=k_{\mathrm{des}}^{\mathrm{ML}}\right)$.

Then, the adsorption rate constants for $\mathrm{Cd}^{2+}$, for the ligand and the complex can be calculated by:

$\left\{\begin{array}{c}k_{\mathrm{ads}}^{\mathrm{M}}=\frac{b_{\mathrm{M}} k_{\mathrm{des}}^{\mathrm{M}}}{\theta} \\ k_{\mathrm{ads}}^{\mathrm{L}}=\frac{b_{\mathrm{L}} k_{\mathrm{des}}^{\mathrm{L}}}{\theta} \\ k_{\mathrm{ads}}^{\mathrm{ML}}=k_{\mathrm{ads}}^{\mathrm{L}}\end{array}\right\}$

The diffusion coefficient of $\mathrm{Cd}^{2+}$ in water, $D_{\mathrm{M}}$ was fixed at $7.07 \times 10^{-6} \mathrm{~cm}^{2} \mathrm{~s}^{-1}$ (Lide 2004). We assumed that the diffusion coefficient of the complex in water was equal to that of the free ligand $D_{\mathrm{L}}$ but lower or equal to that of $\mathrm{Cd}^{2+}\left(D_{\mathrm{M}}\right)$; then, $D_{\mathrm{ML}}=D_{\mathrm{L}}$ ranged between $10^{-8}$ and $7.07 \times 10^{-6} \mathrm{~cm}^{2} \mathrm{~s}^{-1}$ (Pinheiro et al. 1994).

For the plant parameters, the $I_{\max }$ and $K_{\mathrm{m}}$ ranges were derived from different studies reviewed by Lux et al. (2011) for agricultural crops including wheat, maize, soybean. Cadmium hyperaccumulators were not 
Table 1 Parameter domain of the Cd phytoavailability model in non-polluted agricultural soils

\begin{tabular}{|c|c|c|c|c|c|c|}
\hline Parameters & Descriptions & Min & Max & $\log _{10}(\operatorname{Min})^{\dagger}$ & $\log _{10}(\mathrm{Max})^{\dagger}$ & Units \\
\hline$D_{\mathrm{M}}^{*}$ & diffusion coefficient of $\mathrm{Cd}^{2+}$ in water & $7.07 \times 10^{-6}$ & & & & $\mathrm{~cm}^{2} \mathrm{~s}^{-1}$ \\
\hline$T^{*}$ & uptake duration & 2592000 & & & & $\mathrm{~s}$ \\
\hline$T M_{0}^{\dagger \dagger}$ & initial content of total $\mathrm{Cd}$ in soil & 0.01 & 2 & & & $\mu \mathrm{g} \mathrm{g}^{-1}$ \\
\hline$p H^{\dagger \dagger}$ & soil $\mathrm{pH}$ value & 4.4 & 9.14 & & & \\
\hline$S O C^{\dagger \dagger}$ & soil organic carbon content & 0.0017 & 7.9 & & & g $100 \mathrm{~g}^{-1}$ \\
\hline $\mathrm{Ca}$ & calcium concentration in solution & 0.1 & 10 & -1 & 1 & $\mu \mathrm{mol} \mathrm{cm}{ }^{-3}$ \\
\hline$F_{\mathrm{DOC} / \mathrm{SOC}}$ & dissolved organic carbon fraction & 0.05 & 0.4 & & & g $100 \mathrm{~g}^{-1}$ \\
\hline$\theta$ & soil volumetric water content & 0.05 & 0.45 & & & $\mathrm{~cm}^{3} \mathrm{~cm}^{-3}$ \\
\hline$f$ & soil impedance factor & 0.01 & 0.55 & & & $\mathrm{~cm}^{2} \mathrm{~cm}^{-2}$ \\
\hline$D_{\mathrm{L}}$ & diffusion coefficient of ligand in water & $10^{-8}$ & $7.07 \times 10^{-6}$ & -8 & -5.151 & $\mathrm{~cm}^{2} \mathrm{~s}^{-1}$ \\
\hline$\rho$ & soil bulk density & 1.3 & 1.7 & & & $\mathrm{~g} \mathrm{~cm}^{-3}$ \\
\hline$K_{\mathrm{d}}^{\mathrm{L}}$ & soil/solution partitioning coefficient of ligand & 1 & 50 & & & $\mathrm{~cm}^{3} \mathrm{~g}^{-1}$ \\
\hline$k_{\mathrm{des}}^{\mathrm{M}}$ & desorption rate constant of $\mathrm{Cd}^{2+}$ & $10^{-6}$ & $5.5 \times 10^{-4}$ & -6 & -3.260 & $\mathrm{~s}^{-1}$ \\
\hline$k_{\mathrm{des}}^{\mathrm{L}}$ & desorption rate constant of ligand & $10^{-6}$ & $5.5 \times 10^{-4}$ & -6 & -3.260 & $\mathrm{~s}^{-1}$ \\
\hline$k_{\mathrm{d}}$ & dissociation rate constant of complex in solution & $10^{-6}$ & $10^{-2}$ & -6 & -2 & $\mathrm{~s}^{-1}$ \\
\hline$I_{\max }$ & maximum absorption rate of $\mathrm{Cd}^{2+}$ by plant root & $10^{-8}$ & $10^{-6}$ & -8 & -6 & $\mu \mathrm{mol} \mathrm{cm} \mathrm{c}^{-2} \mathrm{~s}^{-1}$ \\
\hline$K_{\mathrm{m}}$ & affinity coefficient & $10^{-6}$ & $10^{-3}$ & -6 & -3 & $\mu \mathrm{mol} \mathrm{cm}{ }^{-3}$ \\
\hline$v_{0}$ & water velocity at root surface & $10^{-9}$ & $5 \times 10^{-6}$ & -9 & -5.301 & $\mathrm{~cm} \mathrm{~s}^{-1}$ \\
\hline$r_{0}$ & plant root radius & 0.005 & 0.05 & & & $\mathrm{~cm}$ \\
\hline$r_{1}$ & half distance between plant roots & 0.1 & 1 & & & $\mathrm{~cm}$ \\
\hline
\end{tabular}

\footnotetext{
${ }^{\dagger}$ Maximum and minimum values were applied in $\log _{10}$-transformed form

${ }^{\ddagger} D_{\mathrm{M}}$ and $T$ were constants in the model

${ }^{\dagger} T M_{0}, p H, S O C$ were actual values from public data bases
}

considered. The ranges for the water flux at the root surface $v_{0}$ and for the root radius $r_{0}$ were also derived from values summarized in the literature for crop species (Adhikari and Rattan 2000; Barber 1995; Williams and Yanai 1996). Finally, the half distance between two root axes $\left(r_{1}\right)$ was calculated from the root length density range for agriculture crops $R_{\mathrm{d}}=0.3$ to $20 \mathrm{~cm}$ root $\mathrm{cm}^{-3}$ soil (Metselaar and De Jong van Lier 2011; Williams and Yanai 1996) following the formula:

$r_{1}=\frac{1}{\sqrt{\pi R_{\mathrm{d}}}}$

The impedance factor $f$ was chosen in the range of 0.01 to 0.55 , with boundary limitations linked to $\theta$ based on data from (Chou et al. 2012; Tinker and Nye 2000):

$0.009+0.059 \theta+1.039 \theta^{2} \leq f \leq 0.038+1.023 \theta+0.237 \theta^{2}(27)$

All parameter ranges are summarized in Table 1 . The ranges for the parameters were chosen to be representative of the uncontaminated French agricultural soils.
The design of virtual experiments and data processing

In total, there were 18 parameters allowed to vary as summarized in Table 1. Three of them $\left(T M_{0}, p H, S O C\right)$ were directly derived from actual values of the databases. The remaining 15 were sampled using quasirandom sampling with low discrepancy sequences from a uniform distribution (Saltelli et al. 2004). The parameters whose ranges covered more than two orders of magnitude were sampled within the $\log _{10}$-transformation of their ranges to ensure an uniform distribution of the sampling values over different orders of magnitude. In order to guarantee that the simulated situations were realistic, we discarded all the combinations of parameter values that did not fulfill the following constraint.

$5 \leq K_{\mathrm{d}}^{\mathrm{M}} \leq 10^{6} \mathrm{~cm}^{3}$ solution $\mathrm{g}^{-1}$ soil

To analyze the contribution of the complex to uptake and the kinetics limitation of sorption and complexation, four models were ran for each combination of 
parameters: the full model (Eqs. 5-8) and the nocomplex model (Eqs. 1-2), both of them with kinetics (the kinetics constants for sorption and complexation were allowed to vary within their ranges (Table 1)), or at equilibrium by setting the kinetics constants $k_{\mathrm{des}}{ }^{\mathrm{M}}$, $k_{\mathrm{des}}^{\mathrm{L}}$, and $k_{\mathrm{des}}{ }^{\mathrm{ML}}$ all at $1000 \mathrm{~s}^{-1}$, and $k_{\mathrm{d}}$ at $10^{5} \mathrm{~s}^{-1}$, respectively. These values were determined from preliminary tests aiming at having equilibrium indices equal to 1 (see below).

Some derived variables were calculated to help understanding the outputs of phytoavailability models. The relative importance of convection and diffusion fluxes of $\mathrm{Cd}^{2+}$ at the root surface was assessed by calculating the dimensionless Péclet number (Roose et al. 2001):

$P e=\frac{v_{0} r_{0}}{f \theta D_{M}}$

If $P e$ is lower than 1 , then the convection is less important compared with the diffusion of $\mathrm{Cd}^{2+}$ in soil.

The mean equilibrium index for the sorption kinetics of $\mathrm{Cd}^{2+}$ at root surface for the absorption duration $\left(E_{\mathrm{CdS}}\right)$ is calculated as follows:

$$
E_{\mathrm{CdS}}=\frac{\int_{0}^{T}\left(\frac{C_{\mathrm{MS}}}{C_{\mathrm{M}}}\right) d t}{T \frac{\theta k_{\mathrm{ads}}^{\mathrm{M}}}{k_{\mathrm{des}}^{\mathrm{M}}}} \quad r=r_{0}
$$

If $E_{\mathrm{CdS}}$ is equal to 1 , then the exchange of $\mathrm{Cd}^{2+}$ between solid phase and solution is not limited by the sorption kinetics.

The mean equilibrium index for the complexation kinetics at the root surface for the absorption duration $\left(E_{\mathrm{CdL}}\right)$ is calculated as follows:

$$
E_{\mathrm{CdL}}=\frac{\int_{0}^{T}\left(\frac{C_{\mathrm{ML}}}{C_{\mathrm{M}} C_{\mathrm{L}}}\right) d t}{T \frac{k_{\mathrm{a}}^{\text {cond }}}{k_{\mathrm{d}}}} \quad r=r_{0}
$$

If $E_{\mathrm{CdL}}$ is equal to 1, then the complexation kinetics is always at equilibrium at the root surface during the uptake, and $C_{\mathrm{ML}}$ is coupled with $C_{\mathrm{M}}$ and $C_{\mathrm{L}}$ for the diffusion.

The mean net volumic rate of $\mathrm{Cd}^{2+}$ desorption at the root surface $\left(v_{\text {des }}, \mu \mathrm{mol} \mathrm{cm} \mathrm{cm}^{-3}\right.$ soil s$\left.{ }^{-1}\right)$ is calculated as follows:
$v_{\mathrm{des}}=\frac{\int_{0}^{T}\left(k_{\mathrm{des}}^{\mathrm{M}} C_{\mathrm{MS}}-\theta k_{\mathrm{ads}}^{\mathrm{M}} C_{\mathrm{M}}\right) d t}{T} \quad r=r_{0}$

The mean net volumic rate of $\mathrm{CdL}$ dissociation at the root surface $\left(v_{\mathrm{dis}}, \mu \mathrm{mol} \mathrm{\textrm {cm } ^ { - 3 }}\right.$ soil s$\left.{ }^{-1}\right)$ is calculated as follows:

$v_{\mathrm{dis}}=\frac{\int_{0}^{T} \theta\left(k_{\mathrm{d}} C_{\mathrm{ML}}-k_{\mathrm{a}}^{\text {cond }} C_{\mathrm{M}} C_{\mathrm{L}}\right) d t}{T} \quad r=r_{0}$

The contribution of complex to the uptake $(\phi, \%)$ was calculated by the relative difference in the uptake between the full model $\left(U_{\text {cum }}, \mu \mathrm{mol} \mathrm{cm}{ }^{-2}\right)$ and the nocomplex model $\left(U_{\text {cum_no_complex }}, \mu \mathrm{mol} \mathrm{\textrm {cm } ^ { - 2 }}\right)$ :

$\phi=\frac{U_{\text {cum }}-U_{\text {cumnocomplex }}}{U_{\text {cum }}} \times 100$

The phytoavailability models were numerically solved by using FlexPDE Professional 6.32 (PDE Solutions Inc. 2012). The 8707 triplets (total soil $\mathrm{Cd}, \mathrm{pH}$, and SOC) were replicated 12 times in combination with different values for the other parameters to reach a total of 104484 cases to be simulated. About $4.6 \%$ simulations were discarded due to non-convergence of the solution, and about $0.55 \%$ simulations were discarded due to negative contribution of the complex dissociation to the Cd uptake; the negative contribution were attributed to numerical errors because they should have not occurred as the initial $\mathrm{Cd}^{2+}$ concentration was the same for the models with and without complexation. The final number of simulations of the phytoavailability model was 99087 . Data processing and analyses were performed with R (R Core Team 2013).

\section{Results}

Ranking of the model input parameters

The ranking of the parameters are presented by Fig. 1 as standardized regression coefficients (Gan et al. 2014). By construction, some input parameters are correlated (Table S1 in Supplementary materials). For example, the initial $\mathrm{Cd}^{2+}$ concentration $\left(C_{\mathrm{M} 0}\right)$ is correlated with the initial $\mathrm{Cd}$ complex concentration $\left(C_{\mathrm{ML} 0}\right)$, the $\mathrm{Cd}^{2+}$ soil/solution partitioning coefficient $\left(K_{\mathrm{d}}^{\mathrm{M}}\right)$, and the association rate constant for complex ( $\left.k_{\mathrm{a}}^{\text {cond }}\right)$; the soil volumetric water content $(\theta)$ and the soil impedance factor $(f)$ 


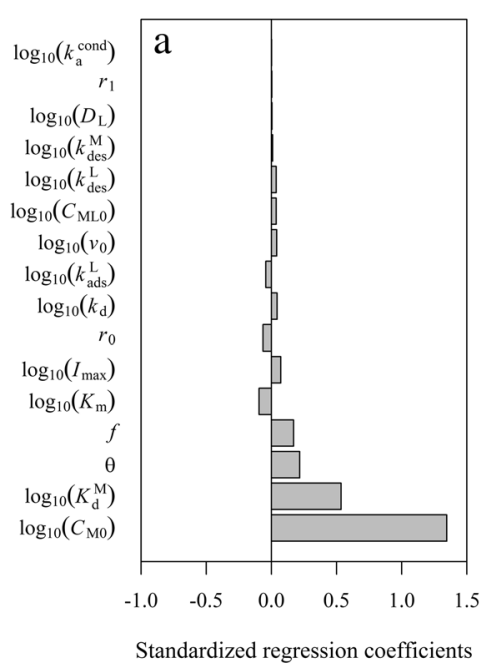

Fig. 1 Rankings of model parameters (a) and primary parameters (b) based on their standardized coefficients for the $\log _{10}$-cumulative $\mathrm{Cd}$ uptake multiple regression. In the Fig. $1 \mathrm{a}, C_{\mathrm{M} 0}$ is the initial concentration of $\mathrm{Cd}^{2+}$ in solution, $K_{\mathrm{d}}^{\mathrm{M}}$ the soil/solution partitioning coefficient of $\mathrm{Cd}^{2+}, \theta$ the soil water content, $f$ the soil impedance factor, $K_{\mathrm{m}}$ the affinity coefficient, $I_{\max }$ the maximum absorption rate of $\mathrm{Cd}^{2+}$ by plant root, $r_{0}$ the root radius, $k_{\mathrm{ads}}^{\mathrm{L}}$ and $k_{\mathrm{des}}^{\mathrm{L}}$ the adsorption and desorption rate constants of ligand, respectively, $v_{0}$ the water velocity at the root surface, $C_{\mathrm{ML} 0}$ the initial concentration of $\mathrm{CdL}$ in the soil solution, $k_{\mathrm{d}}$ and $k_{\mathrm{a}}^{\text {cond }}$ the dissociation and

are also correlated (see Materials and methods). Only parameters which cannot be derived by the others are presented in the figure. Figure 1a shows the ranking of the model parameters (Eqs. 5-8) and Fig. 1b is similar but it shows the primary parameters used to derive some of the model parameters. The model parameters allowed to better understand the relative importance of the different mechanisms while the ranking of the primary parameters was more adapted to traditional field measurements.

The most influential model parameters in Fig. 1a were $C_{\mathrm{M} 0}, K_{\mathrm{d}}^{\mathrm{M}}, \theta$ and $f$. Altogether, these parameters govern the diffusion flux of $\mathrm{Cd}^{2+}$ toward the root surface. The most influential primary parameters in Fig. $1 \mathrm{~b}$ were the soil $\mathrm{pH}$, the total $\mathrm{Cd}$ content $\left(T M_{0}\right)$, the soil organic carbon content $(S O C)$, the calcium concentration in the soil solution $(\mathrm{Ca})$, and the dissolved organic carbon $\left(F_{\text {DOC/SOC }}\right)$. These parameters governed the initial concentration of $\mathrm{Cd}^{2+}$ in the soil solution and its sorption onto the solid phase (see Materials and methods). As shown by Fig. S1 in the Supplementary materials, high initial concentrations of soluble $\mathrm{Cd}^{2+}$ corresponded to low $\mathrm{pH}$, which favored the solubility of $\mathrm{Cd}$, to low

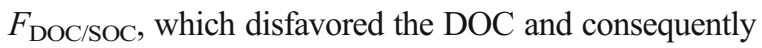

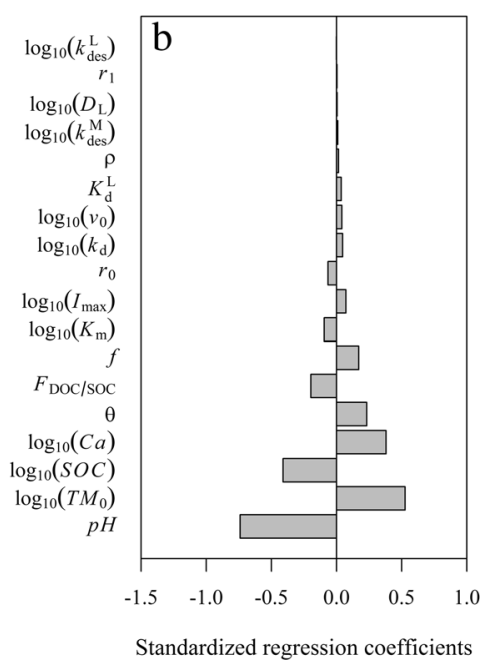

conditional association rate constants of $\mathrm{CdL}$ in solution, respectively, $D_{\mathrm{L}}$ the diffusion coefficient of the ligand in water, $k_{\mathrm{des}}^{\mathrm{M}}$ the desorption rate constant of $\mathrm{Cd}^{2+}$, and $r_{1}$ the half root distance between roots. In the Fig. $1 \mathrm{~b}, \mathrm{pH}$ is the soil $\mathrm{pH}$ value, $T M_{0}$ the initial content of total $\mathrm{Cd}$ in soil, $S O C$ the soil organic carbon content, $\mathrm{Ca}$ the calcium concentration in the soil solution, $F_{\mathrm{DOC} /}$ sOC the fraction of dissolved organic carbon to soil organic carbon, $K_{\mathrm{d}}^{\mathrm{L}}$ the soil/solution partitioning coefficient of the ligand, and $\rho$ the soil bulk density

the formation of $\mathrm{CdL}$ (the latter being also disfavored by low pH (Sauvé et al. 2000b)), to high Ca concentrations (competition with $\mathrm{Cd}$ for complexation) and to low percentages of DOC as humic acids ( $p c_{\mathrm{HA}}$, Eq. 12).

After this first group of parameters related to the diffusion of $\mathrm{Cd}^{2+}$ in soil, the most influential parameters were the root capacity for absorbing $\mathrm{Cd}^{2+}\left(I_{\max }\right.$ and $\left.K_{\mathrm{m}}\right)$ and the root radius $\left(r_{0}\right)$ (Fig. 1a). The root radius also influences the diffusion fluxes towards the root by geometry considerations. These plant parameters were much less influential than the diffusion of $\mathrm{Cd}^{2+}$ meaning that for most of the situations studied here, the uptake was limited by the availability of $\mathrm{Cd}^{2+}$ and not by the root absorption capacity. The least influential parameters were related to the diffusion of CdL and of $\mathrm{L}\left(k_{\mathrm{ads}}^{\mathrm{L}}\right.$, $\left.k_{\mathrm{des}}^{\mathrm{L}}, K_{\mathrm{d}}^{\mathrm{L}}, D_{L}\right)$, the water flux $\left(v_{0}\right)$, the kinetics rate constants for CdL $\left(k_{\mathrm{a}}^{\text {cond }}, k_{\mathrm{d}}\right)$, the desorption rate constants for $\mathrm{Cd}^{2+}\left(k_{\mathrm{des}}^{\mathrm{M}}\right)$, and the between-roots competition $\left(r_{1}\right)$.

Free $\mathrm{Cd}^{2+}$ concentration and $\mathrm{Cd}^{2+}$ convection at the root surface

The speciation calculations indicated that the initial concentration of $\mathrm{Cd}^{2+}\left(C_{\mathrm{M} 0}\right)$ ranged between $1.1 \times$ 
$10^{-10}$ and $9.4 \times 10^{-4} \mu \mathrm{mol} \mathrm{cm}{ }^{-3}$ with a median value of $2.7 \times 10^{-7} \mu \mathrm{mol} \mathrm{cm}{ }^{-3}(0.27 \mathrm{nM})$. This corresponded to a free $\mathrm{Cd}^{2+}$ ion fraction $\left(F_{\mathrm{M} 0}\right)$ between $8.4 \times 10^{-5}$ and 1.0 with a median value of 0.12 ( $12 \%$ of the total soluble $\mathrm{Cd})$. This illustrated that most of the soluble $\mathrm{Cd}$ was complexed with the dissolved organic matter. The statistics for other derived parameters are presented in Table S2 in the Supplementary materials.

Figure 2 shows the $\mathrm{Cd}^{2+}$ concentration at the root surface averaged for the duration of the simulated uptake and expressed as a percentage of the initial concentration. $\mathrm{Cd}^{2+}$ was strongly depleted at the root surface since the average $\mathrm{Cd}^{2+}$ concentration had a median of $1.4 \%$ and for $68 \%$ of the simulations, it was less than $5 \%$ of the initial concentration. This important depletion, which can be assimilated to a zero sink approximation, was not correlated with the magnitude of the uptake. It was characterized by a relatively high root absorption capacity (high $I_{\max }$ and low $K_{\mathrm{m}}$ ), and to a lower extend by a low soil water content and a low soil/solution partitioning for $\mathrm{Cd}^{2+}\left(K_{\mathrm{d}}^{\mathrm{M}}\right)$ (Fig. S2 in the Supplementary materials). Except this, the zero sink approximation was not depending on the range of other input parameters.

There were no situations where $\mathrm{Cd}^{2+}$ accumulated at the root surface (Fig. 2). The highest mean $\mathrm{Cd}^{2+}$ concentrations at the root surface (above 0.95 quantile) ranged between 56 and $98 \%$ of the initial concentration and generally corresponded to low uptakes. For these situations (Fig. S3 in the Supplementary materials), the root uptake capacity was low (low $I_{\max }$ and high $K_{\mathrm{m}}$ ), the potential buffering of $\mathrm{Cd}^{2+}$ by both the solid phase and the complex dissociation was high: high $K_{\mathrm{d}}^{\mathrm{M}}$, and high stability constant for $\mathrm{CdL}\left(K_{\mathrm{S}}^{\text {cond }}\right)$. Additionally, the conditions for diffusion were favorable (high $\theta$ and $f$ ) but the water flux was not particularly higher than for the general cases (Fig. S3).

The distribution of the Péclet number (Eq. 29) is presented by Fig. 3 . The values ranged from $4 \times 10^{-6}$ to 22.7 with a median of $6.2 \times 10^{-3}$. For $56 \%$ of the simulations, the Péclet number values corresponded to diffusion being 100 times convections. These results indicate that regarding the supply of $\mathrm{Cd}^{2+}$ to the root surface, the convection was negligible compared to diffusion for most of the cases studied (Fig. S4 in the Supplementary materials). When the convection was significant, the situations corresponded to a low root uptake capacity $\left(I_{\max }, K_{\mathrm{m}}\right)$ and a high water flux $\left(v_{0}\right)$ (Fig. S5 in the Supplementary materials).
$\mathrm{Cd}^{2+}$ desorption and $\mathrm{Cd}$ complex dissociation at root surface

The mean equilibrium indices for the sorption and complexation kinetics at the root surface, i.e., $E_{\mathrm{CdS}}$ and $E_{\mathrm{CdL}}$ (Eqs. 30 and 31) are shown in Fig. 4. The minimum values of $E_{\mathrm{CdS}}$ and $E_{\mathrm{CdL}}$ were 1.00003 and 1.00508 , respectively. Equilibrium indices greater than one mean that compared to equilibrium conditions, the concentrations of the sorbed or complexed $\mathrm{Cd}^{2+}$ were relatively too high compared to that of free $\mathrm{Cd}^{2+}$ at root surface. The figure shows that the departure from equilibrium was more marked for complexation than for sorption (Fig. 4). For the sorption kinetics, there were only $20.4 \%$ simulations where $E_{\mathrm{CdS}}>10$; while for the complexation kinetics, there were $72.5 \%$ simulations which showed strong departure from equilibrium $\left(E_{\mathrm{CdL}}>10\right)$. Desorption kinetics was close to equilibrium $\left(E_{\mathrm{CdS}}<\right.$ 1.05 ) for around $29 \%$ simulations while for the complex kinetics, approximate equilibrium $\left(E_{\mathrm{CdL}}<1.05\right)$ was observed for only $0.3 \%$ of the simulations.

For sorption, disequilibrium corresponded to cases of a relatively high root uptake capacity, a relatively low soil diffusivity (low $f$ and $\theta$ ) and to both a low $K_{\mathrm{d}}^{\mathrm{M}}$ and a low kinetics of sorption (low $k_{\mathrm{ads}}^{\mathrm{M}}$ and $k_{\mathrm{des}}^{\mathrm{M}}$ ) (Fig. S6 in the supplementary materials). Hence, when the root absorption was high, the buffering of $\mathrm{Cd}^{2+}$ at the root surface by the rate of $\mathrm{Cd}^{2+}$ desorption from the soil matrix was too low. The reason for that was the low desorption rate constants because to reach equilibrium, $k_{\text {des }}^{\mathrm{M}}$ had to be increased to $1000 \mathrm{~s}^{-1}$ (not shown).

For complexation, disequilibrium cases also corresponded to situations where the soil supply of $\mathrm{Cd}^{2+}$ was limiting the uptake (compared to plant absorption capacities), i.e., a high root capacity for $\mathrm{Cd}^{2+}$ uptake and to a lesser extend to a low $\mathrm{CdL}$ dissociation rate constant and a low soil water content $(\theta)$ (Fig. S7 in the supplementary materials). Apart these parameters, the others were little or not discriminant. The departure from equilibrium arose from the difficulty of maintaining $\mathrm{Cd}^{2+}$ concentration at equilibrium with $\mathrm{CdL}$ while root absorbs $\mathrm{Cd}^{2+}$. CdL dissociation was therefore limiting but this was not due to a limitation in CdL availability since its concentration at the root surface was on average the initial one (median of $100.4 \%$ of the initial concentration, not shown). Consequently, the limitation of CdL dissociation comes from the low values of $k_{\mathrm{d}}$. The virtual values of $k_{\mathrm{d}}$ necessary to maintain equilibrium for complexation were very high since, to reach 
Fig. 2 Cd cumulative uptake $\left(\mu \mathrm{mol} \mathrm{cm}{ }^{-2}\right.$ ) against $\mathrm{Cd}^{2+}$ depletion at the root surface expressed as a percentage of the initial concentration $(\%)$

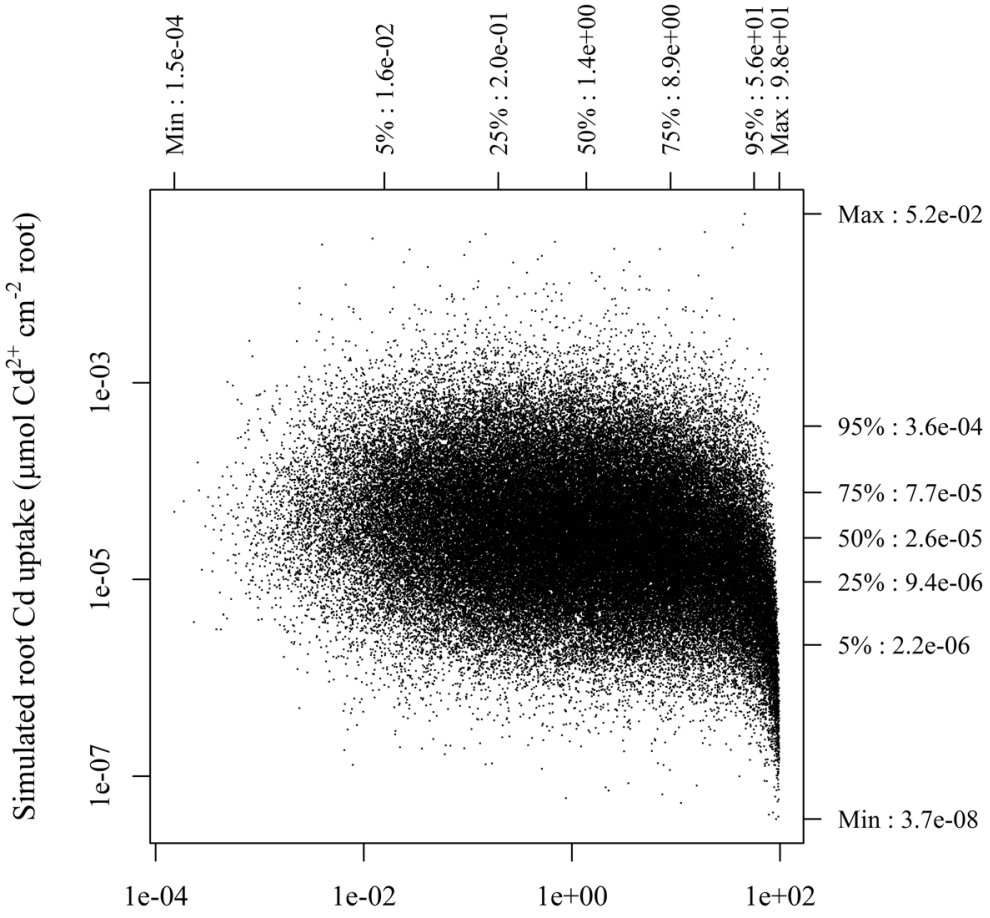

Average $\mathrm{Cd}^{2+}$ concentration at root surface ( $\%$ inital conc.) equilibrium, $k_{\mathrm{d}}$ values of $10^{5} \mathrm{~s}^{-1}$ were necessary (not shown). This explains why within the range tested (max $\left.10^{-2} \mathrm{~s}^{-1}\right), k_{\mathrm{d}}$ was little discriminant of the departure from equilibrium for $\mathrm{CdL}$ dissociation (Fig. S7).

The departure from equilibrium for the sorption and complexation kinetics had a significant effect on the uptake (Fig. 5), which was increased by $21 \%$ (median value) if equilibrium was forced by setting kinetics rate constants at very high values. The influence of kinetics was weak for very low and very high uptakes. Fig. S8 (Supplementary materials) shows the uptake simulated by the no-complex model with and without kinetic for
Fig. 3 Kernel density functions of the Péclet number illustrating the relative importance between convection and diffusion

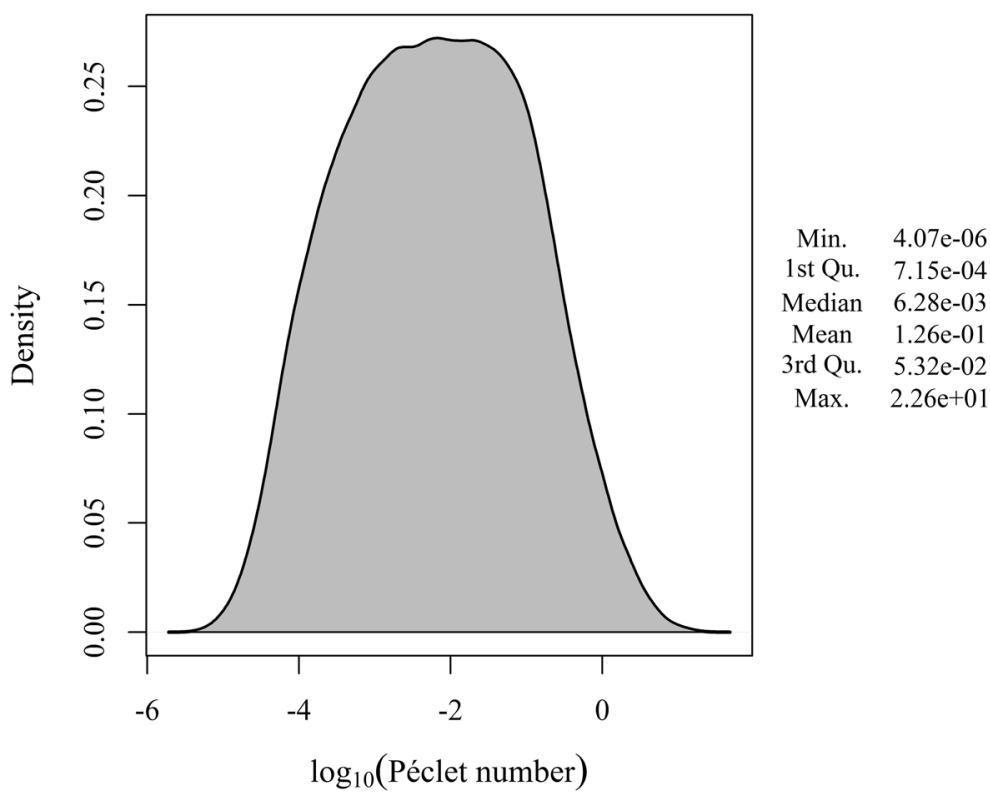




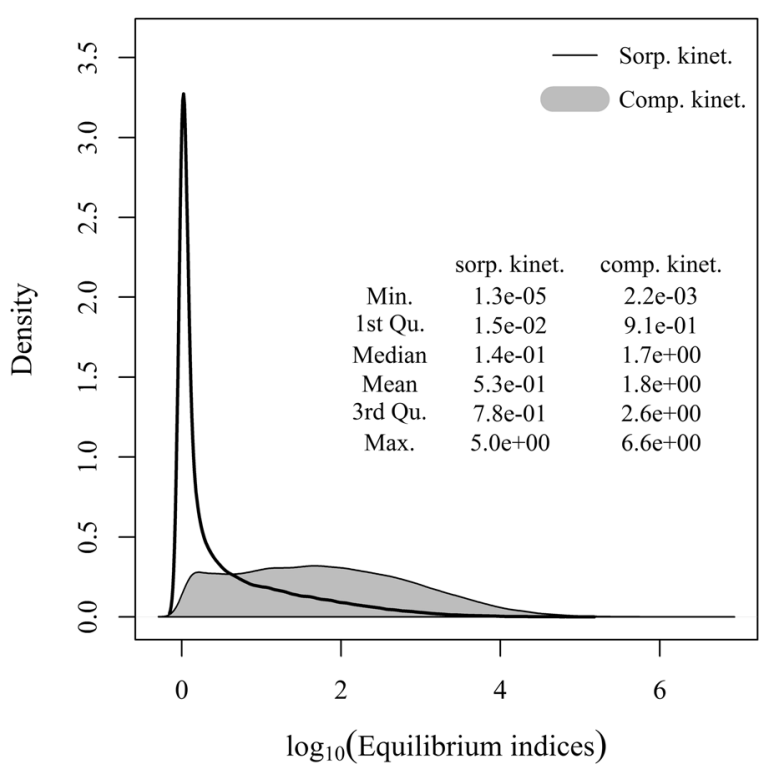

Fig. 4 Kernel density functions of mean equilibrium indices for complexation (comp.) and for sorption (sorp.) kinetics at root surface. The statistics of the two indices are given in the inset

sorption. It can be seen that considering or not the sorption kinetics gave very similar simulated uptake. This shows that when there is no complex, the sorption kinetics is of little importance.

Figure 6 (x axis) shows the mean net volumic rates of $\mathrm{Cd}^{2+}$ desorption ( $v_{\text {des }}$; Eq. 32 ) against CdL dissociation

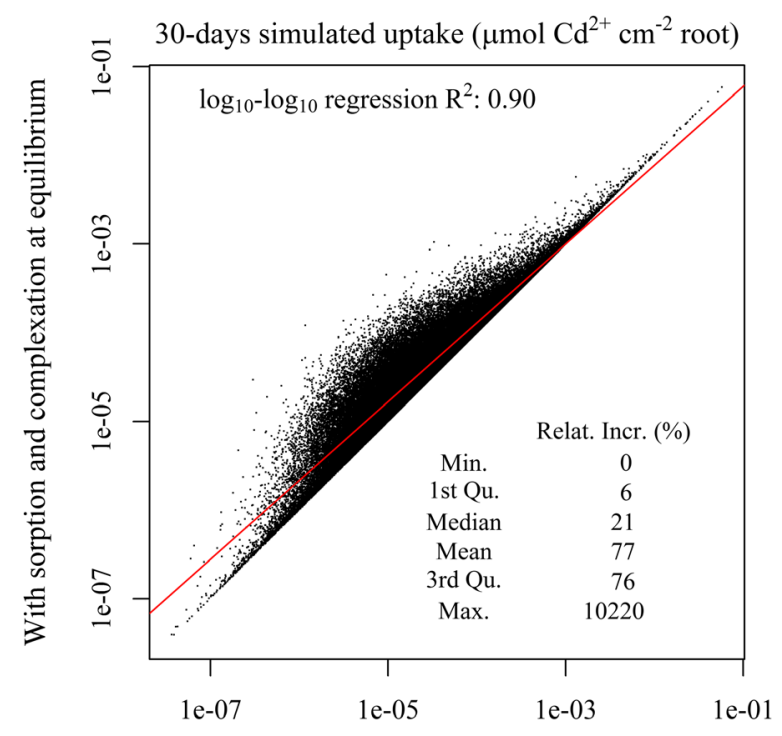

With kinetics for sorption and complexation

Fig. $5 \mathrm{Cd}$ cumulative uptake with sorption and complexation kinetics at equilibrium $\left(\mu \mathrm{mol} \mathrm{cm}{ }^{-2}\right)$ against $\mathrm{Cd}$ cumulative uptake with sorption and complexation kinetics $\left(\mu \mathrm{mol} \mathrm{cm}{ }^{-2}\right)$

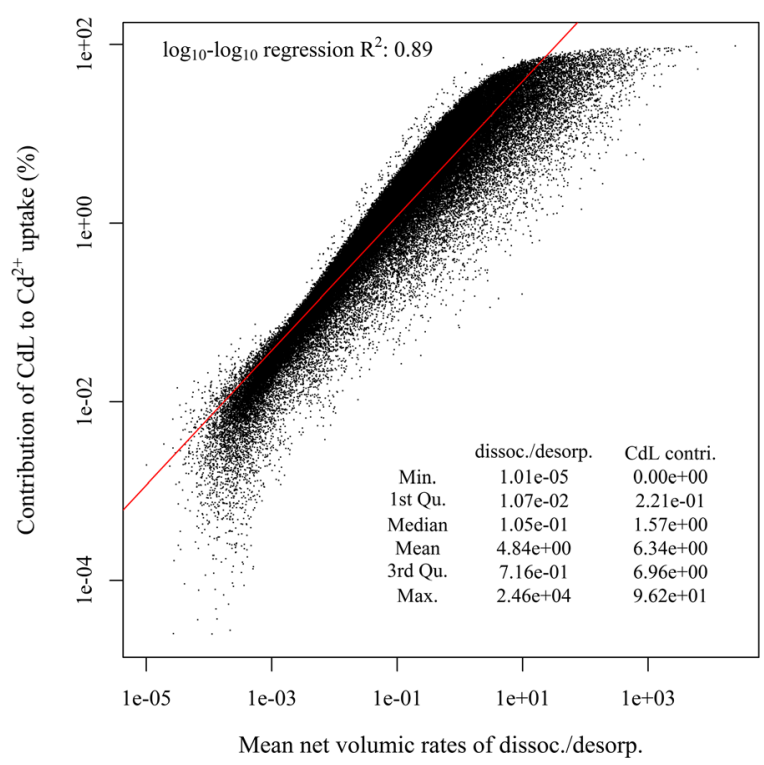

Fig. 6 Contribution of $\mathrm{CdL}$ to the uptake (\%) against the ratio between the mean net volumic rates $\left(\mu \mathrm{mol} \mathrm{cm} \mathrm{cm}^{-3}\right.$ soil s$\left.{ }^{-1}\right)$ of $\mathrm{CdL}$ dissociation (dissoc.) and of $\mathrm{Cd}^{2+}$ desorption (desorp.) at root surface

$\left(v_{\mathrm{dis}} ;\right.$ Eq. 33$)$ at the root surface during the root absorption. The two mean net volumic rates were always both positive (not shown), which was consistent with the fact that the two equilibrium indices $\left(E_{\mathrm{CdL}}\right.$ and $\left.E_{\mathrm{CdS}}\right)$ were always greater than one. For $78.9 \%$ simulations, values of $v_{\text {des }}$ were greater than those of $v_{\text {dis. }}$.

Contribution of $\mathrm{Cd}$ complex to uptake and the free $\mathrm{Cd}^{2+}$ model approximation

The contribution of complex to $\mathrm{Cd}^{2+}$ uptake (Eq. 34) is presented in Fig. 6 (y axis). In the no complex model (Eqs. 1-2), the $\mathrm{Cd}^{2+}$ desorption is virtually enhanced compared to the desorption in the full model (Eqs. 5-8) because it partially compensated the lack of buffering by the complex formalized in the full model. Therefore, the complex contribution estimated by our calculations might be underestimated.

The contribution of CdL ranged from 0 to $96 \%$ (with $\mathrm{CdL} /$ without $\mathrm{CdL}=25$ ) with a median of $1.6 \%$ and a third quartile of $7.0 \%$. For $69.5 \%$ of the simulations, CdL contribution was less than $5 \%$ of the uptake (with $\mathrm{CdL} /$ without $\mathrm{CdL}=1.05$ ). The contribution of $\mathrm{CdL}$ did not show any relationship with the uptake nor with the dissociation or with the desorption rates (not shown). However, the relative importance of the volumic dissociation and desorption rates $\left(v_{\mathrm{dis}}, v_{\mathrm{des}}\right)$ strongly correlated with the contribution of CdL to the uptake (Fig. 6). When the volumic rate of $\mathrm{CdL}$ dissociation was lower 

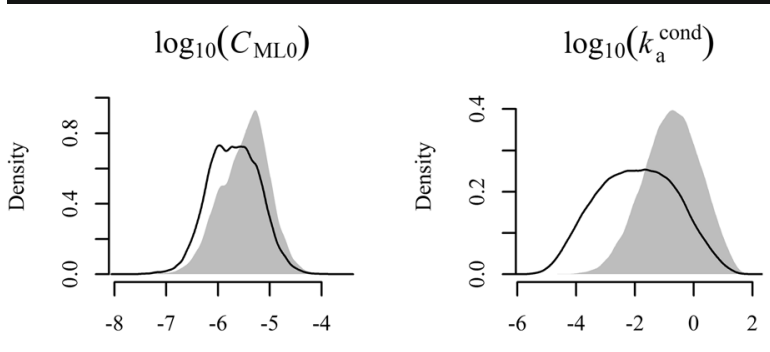

$\log _{10}\left(I_{\max }\right)$
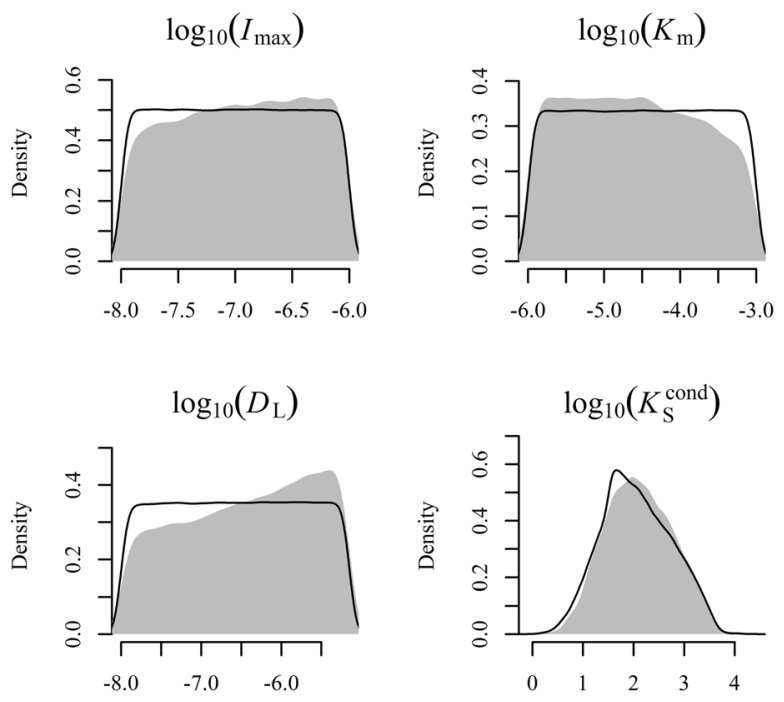

Fig. 7 Kernel density functions of influential parameters for all simulations (solid lines) and simulations where contribution of CdL to the uptake was greater than $10 \%$ of the uptake (grey areas). In the figure, $C_{\mathrm{ML} 0}$ is the initial concentration of $\mathrm{CdL}$ in the soil solution, $k_{\mathrm{a}}^{\text {cond }}$ and $k_{\mathrm{d}}$ the conditional association and the dissociation rate constants of $\mathrm{CdL}$ in the soil solution, $k_{\mathrm{des}}^{\mathrm{M}}$ the desorption

than the volumic rate of $\mathrm{Cd}^{2+}$ desorption, the contribution of CdL to the uptake had a median of $0.7 \%$ and a 95 percentile of $9.3 \%$. When the rate of CdL dissociation was greater than the rate of $\mathrm{Cd}^{2+}$ desorption, the complex contribution had a median of $17.7 \%$ and a 95 percentile of $55.3 \%$. Hence, not surprisingly, CdL contribution was low when CdL dissociation was dominated by desorption rates and conversely.

The highest values of CdL contribution to the uptake $(>10 \%)$ were characterized by a high lability of the complex (high $k_{\mathrm{a}}^{\text {cond }}$ and $k_{\mathrm{d}}$ ) (Fig. 7). The stability constant $K_{\mathrm{S}}^{\text {cond }}$ and therefore the initial concentration of CdL $\left(C_{\mathrm{ML} 0}\right)$ were also greater than the average. The flux of water towards the root was also clearly more important as it transport CdL towards the root. The moderate low the diffusivity of the soil $(f$ and $\theta)$ suggests that the diffusion of $\mathrm{Cd}^{2+}$ was limited compared to the higher root uptake capacity (higher $I_{\max }$ and lower $K_{\mathrm{m}}$ ). The
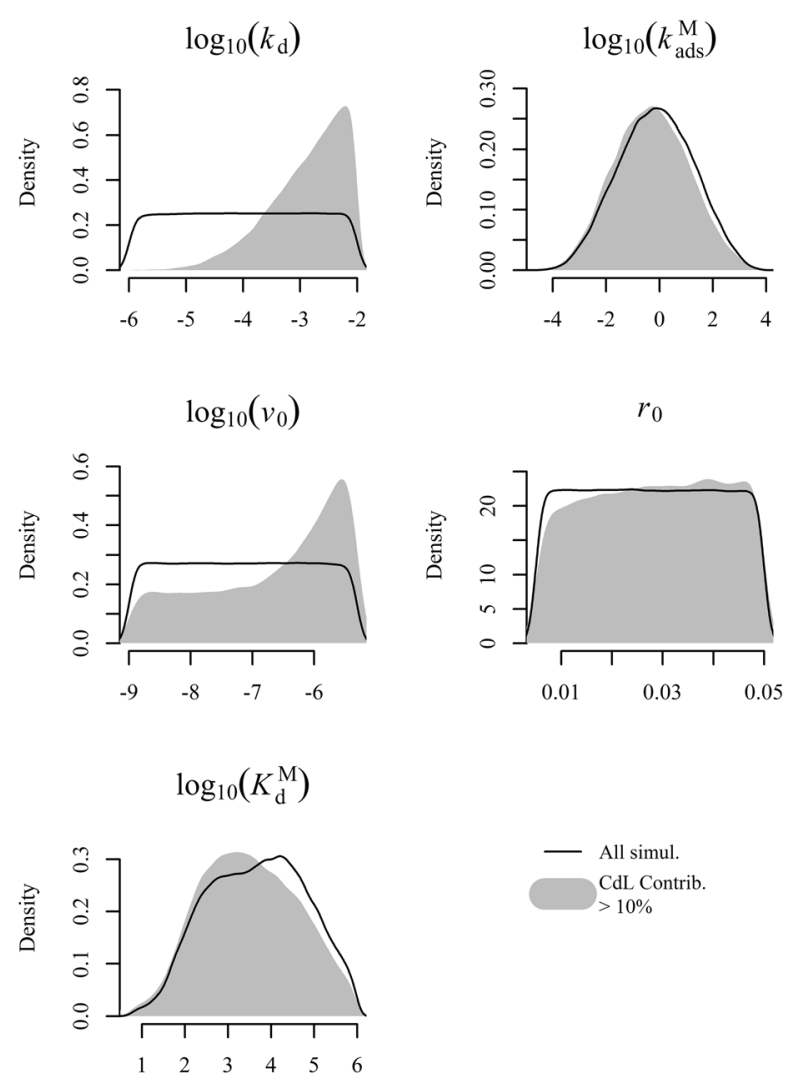

rate constant of $\mathrm{Cd}^{2+}, I_{\max }$ the maximum absorption rate of $\mathrm{Cd}^{2+}$ by plant roots, $K_{\mathrm{m}}$ the affinity coefficient, $v_{0}$ the water velocity at the root surface, $r_{0}$ the root radius, $D_{\mathrm{L}}$ the diffusion coefficient of the ligand in water, $K_{\mathrm{d}}^{\mathrm{M}}$ the soil/solution partitioning coefficient of $\mathrm{Cd}^{2+}$, and $K_{\mathrm{S}}^{\text {cond }}$ the conditional stability constant of $\mathrm{CdL}\left(=k_{\mathrm{a}}^{\text {cond }} /\right.$ $\left.k_{d}\right)$

condition of high complex concentration (consequently high contribution) corresponded to high DOC concentrations (high $F_{\mathrm{DOC} / \mathrm{SOC}}$ values) with a high proportion of fulvic acids (low percentage of humic acids $p c_{\mathrm{HA}}$ ), with a low concentration of $\mathrm{Ca}$ in solution and moderate acid soil conditions (moderate lower pH) (Fig. S9 in the supplementary materials).

Considering that on average the complex contribution to the uptake was low and that the sorption kinetics was little limiting the uptake, we compared the full model (sorption and complexation with both kinetics, Eqs. 5-8) with a simplified model considering only the transports of $\mathrm{Cd}^{2+}$ and its sorption on the solid phase at equilibrium (Eqs. 1-2; $k_{\mathrm{d}}=1000 \mathrm{~s}^{-1}$ ), i.e., the free ion model. The agreement between the full model and the free ion model was good with very little bias (Fig. 8). The error was low with a median of $0.8 \%$ and a third quartile of $6 \%$. The cases where the error was $>10 \%$ corresponded to 


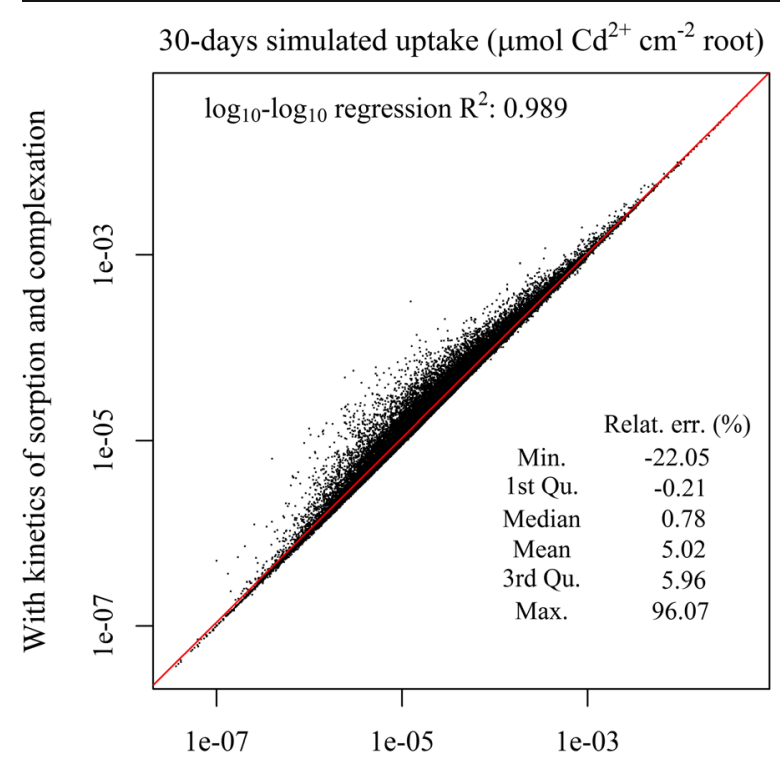

Only free $\mathrm{Cd}^{2+}$ and sorption at equilibrium

Fig. $8 \mathrm{Cd}$ cumulative uptake $\left(\mu \mathrm{mol} \mathrm{cm} \mathrm{cm}^{-2}\right)$ simulated by the full model (kinetics for complexation and sorption) against the cumulative uptake simulated by a model without complex and sorption at equilibrium (free ion model)

situations where the CdL contribution was above $15 \%$ (not shown), which means high supply of labile CdL (Fig. 7). Consequently, for the domain studied, a model not considering the complex and the sorption kinetics was a satisfactory proxy for estimating the availability of $\mathrm{Cd}^{2+}$.

\section{Discussion}

Diffusion of $\mathrm{Cd}^{2+}$ in soil is the main process governing the uptake of $\mathrm{Cd}^{2+}$

For most of the cases, the concentration of $\mathrm{Cd}^{2+}$ at the root surface was very low (median value $0.27 \mathrm{nM}$; Fig. 2). For $98 \%$ of the simulations, the initial concentration of $\mathrm{Cd}^{2+}$ was below $20 \mathrm{nM}$ (not shown), which is consistent with what was reported in the literature for $\mathrm{Cd}^{2+}$ in nonpolluted agricultural soils (Sauvé et al. 2000b). Initial $\mathrm{Cd}^{2+}$ is very low because $\mathrm{Cd}$ easily sorbs onto the soil matrix and forms complexes in solution, particularly with the soluble organic matter. In our results, the dissolved organic carbon (DOC) concentration was between $1.1 \times$ $10^{-2}$ and $234 \mathrm{mg} \mathrm{L}^{-1}$, and the 3 st quarter value was $21.9 \mathrm{mg} \mathrm{L}^{-1}$ (Table S2); this range was a little lower than reported ranges $\left(21-528 \mathrm{mg} \mathrm{L}^{-1}\right.$ ) in the literature (Li et al. 2013; Yin et al. 2002). The free ion fraction $\left(F_{\mathrm{M} 0}\right)$ ranged between $8.4 \times 10^{-5}$ and 1.0 with a median value 0.12 and was comparable with 0 to 0.6 (median value 0.2 ) in Sauvé et al. (2000b) and c.a. 0.3-1.0 in Degryse et al. (2009). Our $F_{\text {Mo }}$ was lower than that in Degryse et al. (2009) because we did not consider too low $\mathrm{pH}$ like in their work (3-8) and the $F_{\mathrm{M} 0}$ decreased with $\mathrm{pH}$ generally.

In our model, the diffusion gradient of $\mathrm{Cd}^{2+}$ results from the balance between the sink strength of the root for uptake $\left(I_{\max }, K_{\mathrm{m}}\right)$ and from the supply of the soil including the diffusivity $(f, \theta)$, the water velocity $\left(v_{0}\right)$, the initial concentration of $\mathrm{Cd}^{2+}, r_{0}$ for geometric considerations, the kinetics of exchanges between sorbed and soluble $\mathrm{Cd}$ and the complexation kinetics of $\mathrm{Cd}$ in the solution. The simulations showed that actually, the initial concentration of $\mathrm{Cd}^{2+}$ and its buffer power (calculated through adsorption and desorption rate constants, $k_{\mathrm{ads}}^{\mathrm{M}}$ andk $\mathrm{k}_{\mathrm{des}}^{\mathrm{M}}$ ) were by far the most influential, followed by the soil diffusivity $(f$ and $\theta$ ) (Fig. 1a). Therefore, the supply of $\mathrm{Cd}^{2+}$ to the root generally determined the uptake in agricultural soils, which is well established experimentally and which corresponds to the good predictive value of the free ion activity model (Parker and Pedler 1997).

The relative importance between convection and diffusion, i.e., the Péclet number was in general very low, showing that diffusion was the dominant process for the supply of the root surface with $\mathrm{Cd}^{2+}$. Diffusion was not only the main process influencing Cd uptake but it was for most of the cases the limiting factor. Indeed, the root capacity for absorption $\left(I_{\max }, K_{\mathrm{m}}\right)$ was not very influential, meaning that it was generally not limiting the uptake. Consequently, a moderate uncertainty in the values of $I_{\max }$ and $K_{\mathrm{m}}$ or moderate changes in these parameters due to the plant functioning are expected to have little influence on the simulated uptake for most of the cases. This could explain why, for example, the 3 times increase in the root power from the basis toward the tip of sunflower roots (Laporte et al. 2013, 2014) was not experimentally observed to impact the Cd uptake of plants with different root architecture (different numbers of root tips) (Laporte et al. 2015). The low influence of $I_{\max }$ and $K_{\mathrm{m}}$ on the uptake is related to the nanomolar range for initial concentration of $\mathrm{Cd}^{2+}$. In the literature, observed differences in Cd uptake between plant species cultivated on the same soil can generally be explained by the higher initial availability of $\mathrm{Cd}^{2+}$ (Stritsis et al. 2014) but it cannot be excluded that variations in root architecture impacting soil exploration (de Dorlodot et al. 2007) or rootdeduced changes in the rhizosphere including $\mathrm{pH}$ could also explain these differences (Hinsinger et al. 2009). 
Because of the low Péclet number (Fig. 3) and of the very low $\mathrm{Cd}^{2+}$ concentration at the root surface (Fig. 2), neglecting convection or considering a null concentration of $\mathrm{Cd}^{2+}$ at the root surface makes sense for many simulations. However, cases where these hypotheses do not hold may be of significant importance in the field. For example, the simulations indicated that significant contribution of convection to uptake is expected for low root capacity uptake and high water flux (Fig. S5 in the supplementary materials). This can actually be the case for maize, an important crop species that can have water flux of $10^{-6}$ to $10^{-5} \mathrm{~cm} \mathrm{~s}^{-1}$ (Varney and Canny 1993) and $I_{\max }$ around $10^{-8} \mu \mathrm{mol} \mathrm{cm} \mathrm{cm}^{-2} \mathrm{~s}^{-1}$ (Lux et al. 2011).

Neglecting convection and assuming a steady state has been attained at the root surface are hypotheses of great interest for building simple models for predicting the uptake. The uptake of $\mathrm{Cd}^{2+}$ could then be calculated from the time integration of a diffusion flux of $\mathrm{Cd}^{2+}$ within a diffusion layer of thickness $\delta$ with a null concentration at the root surface and with the initial concentration at $\delta$. This kind of model would give an analytical solution for the time integration, which is much more convenient than the numerical integration of the partial differential equations developed in our model. The difficulty is to estimate $\delta$, which depends on the diffusivity of the soil $(f$ and $\theta)$, on $r_{0}$, and on the buffer power for $\mathrm{Cd}^{2+}$.

$\mathrm{Cd}^{2+}$ in solution is generally buffered by desorption with little influence of kinetics

The importance of $\mathrm{Cd}^{2+}$ diffusion in soil also includes the buffering of the $\mathrm{Cd}^{2+}$ by the desorption from the solid phase as illustrated by the ranking of the partitioning coefficient $K_{\mathrm{d}}^{\mathrm{M}}$ in Fig. 1a. The relatively low contribution of the $\mathrm{Cd}$ complex to root uptake as well as the mean net volumic rate of dissociation $v s$ desorption at the root surface (Fig. 6) showed that generally the buffering of $\mathrm{Cd}^{2+}$ came from sorbed $\mathrm{Cd}^{2+}$ pool; and little from the dissociation of the complex.

Although the buffer power for $\mathrm{Cd}^{2+}$ is a key parameter, the kinetics of sorption/desorption was much less influential. In the no-complex model, forced equilibrium for sorption kinetics did not result in a large increase of the uptake (Fig. S8); the desorption rate constant $\left(k_{\mathrm{des}}^{\mathrm{M}}\right)$ was likely enough high, making the desorption of sorbed $\mathrm{Cd}$ able to maintain quasi-equilibrium conditions when the root absorbed $\mathrm{Cd}^{2+}$. We tested rate constants for desorption from $10^{-6}$ to $5 \times 10^{-4} \mathrm{~s}^{-1}$. The upper range correspond to acid soils with low sorption capacity (Ernstberger et al.
2005; Wang et al. 2009) and were the highest values we were able to find for soils in the literature.

Without Cd complex in solution, the sorption kinetics showed almost negligible influence on the uptake (Fig. S8). In the presence of a complex, the kinetics of desorption is expected to be even less influential as the complex dissociation also contributes to buffer $\mathrm{Cd}^{2+}$ and the solid phase is then less mobilized. Additionally, when the buffer power for $\mathrm{Cd}^{2+}$ is accounted for by considering the $\mathrm{pH}$, the $\mathrm{SOC}$, the concentration of total $\mathrm{Cd}$ and $\mathrm{Ca}$ in solution, the desorption rate constant $k_{\mathrm{des}}^{\mathrm{M}}$ is little influential (Fig. 1b). Therefore, as shown by the very good agreement between the full model with kinetics and the free ion model without sorption kinetics, the sorption kinetics was generally not necessary and sorption/ desorption could be simplified by a constant buffer power in the model. The particular cases where this does not hold correspond to situations where the root absorption was high, and where the kinetics constant for sorption and desorption were very low (Fig. S6).

Strong complexation kinetic limitation and low complex contribution to uptake

The complexation kinetics showed much stronger disequilibrium than the sorption kinetics (Fig. 4). To simulate equilibrium, a $k_{\mathrm{d}}$ (rate constant for CdL dissociation) of $10^{5} \mathrm{~s}^{-1}$ was required. Considering that the sorption kinetics is of little influence (Fig. S8), the significant increase of uptake when the full model is forced to equilibrium (Fig. 5) can be attributed to the forced equilibrium for the complexation kinetics. As the $\mathrm{CdL}$ concentration at the root surface was not depleted (median of $100.4 \%$ of the initial concentration), this increase of uptake indicates the strong limitation of the complex dissociation kinetics. The dissociation of $\mathrm{CdL}$ in soil solution was not enough rapid to supply the roots with $\mathrm{Cd}^{2+}$ indicating that generally, the lability of the complex (Degryse et al. 2006) was low to compete with the buffering by desorption from solid phase.

For $69.5 \%$ simulations not including the complex in the model did not resulted in an important error $(<5 \%)$ when simulating $\mathrm{Cd}^{2+}$ uptake (not shown). These simulations corresponded to low rate constants for association and dissociation (meaning relatively inert complex in the soil solution), high soil/solution partitioning for $\mathrm{Cd}^{2+}$, and low water flux. The increase in uptake by the presence of $\mathrm{CdL}$ observed in our work was lower than those reported elsewhere in hydroponics (Degryse et al. 
2012; Panfili et al. 2009). Indeed, strong increase in uptake due to CdL has been demonstrated in system with no buffer power from a solid phase (Degryse et al. 2006; Panfili et al. 2009). When a sorbing phase exists, both desorption and CdL dissociation can buffer $\mathrm{Cd}^{2+}$ at the root surface. We observed that the mean net volumic rates of $\mathrm{Cd}^{2+}$ desorption was generally dominating that of CdL dissociation. The concentration of sorbed $\mathrm{Cd}$ was on average 946 and 44 times that of CdL in solution at the beginning and for the whole duration of root absorption, respectively. This makes the sorbed pool a greater reserve for buffering the free $\mathrm{Cd}^{2+}$ compared to CdL. Additionally, the strong limitation of complexation kinetics discussed above also resulted in the low contribution of the complex. Consistent with this, the situations where the complex contribution was found high corresponded to high $k_{\mathrm{a}}^{\text {cond }}$ and $k_{\mathrm{d}}$ (Fig. 7), meaning highly labile complex for which the kinetics limitation was lower. Hence, at the root surface, the higher concentration of sorbed $\mathrm{Cd}^{2+}$ compared to $\mathrm{CdL}$ together with a strong kinetic limitation in $\mathrm{CdL}$ dissociation resulted in a high rate of desorption compared to $\mathrm{CdL}$ dissociation explaining the general low contribution of the complex to the uptake.

Our work concentrated on the endogenous dissolved soil organic matter and did not include exudation for simplification. In the literature, exudation of low molecular weight organic acids (LMWOA) has been hypothesized to increase the phytoavailability of Cd (Cieśliński et al. 1998; Nigam et al. 2001). However, in soil conditions, the mechanisms responsible for that are not easy to elucidate. Correlations between LMWOA concentration in the rhizosphere and plant $\mathrm{Cd}$ uptake can be explained by an increase in Cd phytoavailability due to an acidification associated with the organic acid exudation (Jones 1998). When supplied to the plant, LMWOA-Cd complexes can increase the uptake in nutrient solution because there is no solid phase to compete for the buffering of $\mathrm{Cd}^{2+}$ (Panfili et al. 2009). In soil, the increase in the plant Cd uptake reported in the literature (Nigam et al. 2001) can be explained by the fact that LMWOA-Cd complexes are supplied at very high concentrations, making the $\mathrm{Cd}$ complexes the main source of $\mathrm{Cd}$.

The ligands exuded by roots form complexes with $\mathrm{Cd}^{2+}$, which should result in a decrease in the free ion concentration, all the more so as the buffer power is low (Lin et al. 2014). In soils with a low buffering capacity for $\mathrm{Cd}^{2+}$, root exudation is thus expected to decrease the uptake. In soils with a high buffering capacity for $\mathrm{Cd}^{2+}$, the free ion concentration should decrease little while the $\mathrm{Cd}$ complex concentration increases. If the $\mathrm{Cd}$ complexes are absorbed as it is assumed for phytosiderophores (Ptashnyk et al. 2011), the uptake should increase. Otherwise, the additional $\mathrm{Cd}$ complex might increase the uptake only if they can buffer $\mathrm{Cd}^{2+}$ more strongly than the solid phase does, which is questionable considering the kinetic limitation suggested by our results.

Assessing the phytoavailability of $\mathrm{Cd}^{2+}$ in agricultural soils

Considering that the contribution of CdL was low (Fig. 6) and that the sorption kinetics was little influential (Fig. S8), a free ion activity model assuming that $\mathrm{CdL}$ was totally inert and only considering $\mathrm{Cd}^{2+}$ transport and buffering at equilibrium was a good approximation for assessing the phytoavailability of $\mathrm{Cd}$ in agricultural soils within the ranges of the soil characteristics studied here (Fig. 8). This simplified model can be used to compare and rank different soils differing quite substantially. The effort is to be concentrated on the estimation of the initial $\mathrm{Cd}^{2+}$ concentration and on the soil buffer power for the free ion as these parameters are not frequently determined in current soil analyses. Here, the initial concentration of $\mathrm{Cd}^{2+}$ and its buffer power were derived from the $\mathrm{pH}$, the total concentration of $\mathrm{Cd}$ in the soil, the $\mathrm{SOC}$, the concentration of soluble $\mathrm{Ca}^{2+}$ and the DOC $\left(F_{\text {DOC/SOC }}\right)$ by using statistical models for the soil/solution partitioning of $\mathrm{Cd}$ and speciation calculations. This can be an approach for deriving the initial concentration of $\mathrm{Cd}^{2+}$ and its buffer power from parameters commonly measured in the field assuming that the underlying statistical model for the soil/solution partitioning are correctly calibrated. Otherwise, it is recommendable to directly measure these parameters from the soil to be characterized. The initial $\mathrm{Cd}^{2+}$ concentration can be determined by specific electrode or by resin-based methods (Cornu et al. 2009, 2011; Schneider et al. 2009) while the buffer power for the free ion could be assessed by sorption/desorption experiments including the determination of the free ion fraction at equilibrium.

If one is interested in minimizing the prediction error risk for a particular soil+plant situation, the abovementioned simplified free-ion model may not be appropriate. Then, the first step would be to examine if it is necessary to account for the complex contribution by examining limit values for the kinetics constant $k_{\mathrm{a}}^{\text {cond }}$ and $k_{\mathrm{d}}$ and for the water flux (Fig. 7). If the complex 
has to be accounted for, the kinetics of complexation has to be included as it is expected to strongly influence the contribution of CdL. If the complex could be assumed as inert, the phytoavailability can be estimated from the simple transport model with buffer power of $\mathrm{Cd}^{2+}$ in soil.

Here, we concentrate on a phytoavailability modelling for soil diagnosis. From our approach and because the between-roots competition $\left(r_{1}\right)$ was little influential, the uptake by a growing root system can be achieved by integrating the uptake along with a linear or exponential root growth model following the approach proposed by Barber (1995) or possibly by considering the root architecture (Schnepf et al. 2011) to account for spatial heterogeneity in $\mathrm{Cd}$ availability in the soil.

\section{Conclusions}

We analyzed a phytoavailability model for $\mathrm{Cd}^{2+}$ in agricultural soils that considers $\mathrm{Cd}$ speciation, transport and kinetics for sorption and for complexation with the soil endogenous dissolved organic matter. The model analysis relied on databases for some agricultural soil parameters.

Our results confirmed that for non-polluted agricultural soils, because the initial concentration of $\mathrm{Cd}^{2+}$ was low, it is the main factor governing the phytoavailability of Cd along with the diffusion properties of the soil and the soil buffer capacity at equilibrium,. As a consequence, the root capacity for absorbing $\mathrm{Cd}^{2+}$ was generally not limiting the uptake and was little influential.

The model outputs indicated that the dissociation of the $\mathrm{Cd}$ complexed to the dissolved endogenous soil organic matter generally contributed little to the root uptake, due to the large reserve of sorbed $\mathrm{Cd}^{2+}$ and because of the strong limitation by the kinetics of the dissociation. The situations where the complex could contribute significantly have been identified. For most of the situations, a model only considering $\mathrm{Cd}^{2+}$ transport and buffering at equilibrium (free ion activity model in soil) would be a good approximation for assessing the phytoavailability of $\mathrm{Cd}$ in agricultural soils. This stresses the need for setting up methods for routinely estimating as accurately as possible the initial $\mathrm{Cd}^{2+}$ concentration in the soil solution and the associated soil buffer power for the free ion.

Acknowledgments This work was supported by the funding ANR 2011 CESA 00801 and by the Z. Lin research grant from the Environment \& Agronomy division of the French National Institute for Agricultural Research (INRA). We are grateful to Mark Irvine (INRA, Centre de Bordeaux, UMR EPHYSE) and Claude Bruchou (INRA PACA, Unité BioSP) for their assistance on high performance computer managing. Authors are very grateful to D. Baize, to Ademe and to Inra Infosol (N. Saby) for making the Aspitet, BDETM and RMQS soil databases available to this work, respectively. The authors are grateful to the reviewers who helped improving this manuscript.

\section{References}

Adhikari T, Rattan RK (2000) Modelling zinc uptake by rice crop using a Barber-Cushman approach. Plant Soil 227:235-242. doi:10.1023/a:1026575032724

Alloway BJ, Steinnes E (1999) Athropogenic additions of cadmium to soils. In: McLaughlin MJ, Singh BR (eds) Cadmium in soils and plants. Kluwer Academic Publishers, Dordrecht

Baize D, Deslais W, Gaiffe M (1999) Anomalies naturelles en cadmium dans les sols de France. Etude Gestion Sols 6:85104

Baize D, Saby N, Deslais W (2007) Teneurs en huit éléments en traces $(\mathrm{Cd}, \mathrm{Cr}, \mathrm{Cu}, \mathrm{Hg}, \mathrm{Ni}, \mathrm{Pb}, \mathrm{Se}, \mathrm{Zn})$ dans les sols agricoles en France résultats d'une collecte de données à l'échelon national. ADEME. Angers, Convention 0375 C0035. p 86

Barber SA (1962) A diffusion and mass-flow concept of soil nutrient availability. Soil Sci 93:39-49

Barber SA (1995) Soil nutrient bioavailability: A mechanistic approach. Wiley

Barber SA, Cushman JH (1981) Nitrogen uptake model for agronomic crops. In: Iskandar JK (ed) Modeling waste water renovation-land treatment, $1 \mathrm{st}$ edn. Wiley, New York

BDETM (C (2013). INRA, Unité INFOSOL, Orléans, France. http://www.gissol.fr/.

Bruand A, Duval O, Cousin I (2004) Estimation des propriétés de rétention en eau des sols à partir de la base de données SOLHYDRO: Une première proposition combinant le type d'horizon, sa texture et sa densité apparente. Étude Gestion Sols 11:12

Cataldo DA, Garland TR, Wildung RE (1983) Cadmium uptake kinetics in intact soybean plants. Plant Physiol 73:844-848

Chaturvedi PK, Seth CS, Misra V (2006) Sorption kinetics and leachability of heavy metal from the contaminated soil amended with immobilizing agent (humus soil and hydroxyapatite). Chemosphere 64:1109-1114. doi:10.1016/j. chemosphere.2005.11.077

Chen W, Chang AC, Wu L, Page AL (2006) Modeling dynamic sorption of cadmium in cropland soils. Vadose Zone $\mathrm{J}$ 5: 1216-1221. doi:10.2136/vzj2006.0037

Chen W, Li L, Chang AC, Wu L, Kwon S-I, Bottoms R (2008) Modeling uptake kinetics of cadmium by field-grown lettuce. Environ Pollut 152:147-152. doi:10.1016/j.envpol.2007.05. 004

Chou HY, Wu LS, Zeng LZ, Chang A (2012) Evaluation of solute diffusion tortuosity factor models for variously saturated soils. Water Resour Res 48:W10539. doi:10.1029/ $2011 \mathrm{wr} 011653$ 
Cieśliński G, Van Rees KCJ, Szmigielska AM, Krishnamurti GSR, Huang PM (1998) Low-molecular-weight organic acids in rhizosphere soils of durum wheat and their effect on cadmium bioaccumulation. Plant Soil 203:109-117. doi: 10.1023/a:1004325817420

R Core Team (2013) R: A language and environment for statistical computing. R Foundation for Statistical Computing, Vienna, Austria

Cornu JY, Denaix L, Schneider A, Pellerin S (2007) Temporal evolution of redox processes and free $\mathrm{Cd}$ dynamics in a metal-contaminated soil after rewetting. Chemosphere 70: 306-314. doi:10.1016/j.chemosphere.2007.06.003

Cornu JY, Parat C, Schneider A, Authier L, Dauthieu M, SappinDidier V, Denaix L (2009) Cadmium speciation assessed by voltammetry, ion exchange and geochemical calculation in soil solutions collected after soil rewetting. Chemosphere 76 : 502-508

Cornu JY, Schneider A, Jezequel K, Denaix L (2011) Modelling the complexation of $\mathrm{Cd}$ in soil solution at different temperatures using the UV-absorbance of dissolved organic matter. Geoderma 162:65-70

de Dorlodot S, Forster B, Pages L, Price A, Tuberosa R, Draye X (2007) Root system architecture: opportunities and constraints for genetic improvement of crops. Trends Plant Sci 12:474-481. doi:10.1016/j.tplants.2007.08.012

Degryse F, Smolders E, Merckx R (2006) Labile Cd complexes increase Cd availability to plants. Environ Sci Technol 40: $830-836$

Degryse F, Smolders E, Parker DR (2009) Partitioning of metals $(\mathrm{Cd}, \mathrm{Co}, \mathrm{Cu}, \mathrm{Ni}, \mathrm{Pb}, \mathrm{Zn})$ in soils: concepts, methodologies, prediction and applications - a review. Eur J Soil Sci 60:590612. doi:10.1111/j.1365-2389.2009.01142.x

Degryse F, Shahbazi A, Verheyen L, Smolders E (2012) Diffusion limitations in root uptake of cadmium and zinc, but Not nickel, and resulting bias in the michaelis constant. Plant Physiol 160:1097-1109. doi:10.1104/pp. 112.202200

Ernstberger H, Davison W, Zhang H, Tye A, Young S (2002) Measurement and dynamic modeling of trace metal mobilization in soils using DGT and DIFS. Environ Sci Technol 36: 349-354. doi:10.1021/es010917d

Ernstberger H, Zhang H, Tye A, Young S, Davison W (2005) Desorption kinetics of $\mathrm{Cd}, \mathrm{Zn}$, and Ni measured in soils by DGT. Environ Sci Technol 39:1591-1597. doi:10.1021/ Es048534d

Gan YJ, Duan QY, Gong W, Tong C, Sun YW, Chu W, Ye AZ, Miao CY, Di ZH (2014) A comprehensive evaluation of various sensitivity analysis methods: A case study with a hydrological model. Environ Model Softw 51:269-285. doi:10.1016/j.envsoft.2013.09.031

Haynes RJ (2005) Labile organic matter fractions as central components of the quality of agricultural soils: An overview. Adv Agron 85:221-268. doi:10.1016/S0065-2113(04)85005-3

Hinsinger P, Bengough AG, Vetterlein D, Young IM (2009) Rhizosphere: biophysics, biogeochemistry and ecological relevance. Plant Soil 321:117-152. doi:10.1007/s11104008-9885-9

Hough RL, Breward N, Young SD, Crout NMJ, Tye AM, Moir AM, Thornton I (2004) Assessing potential risk of heavy metal exposure from consumption of home-produced vegetables by urban populations. Environ Health Persp 112:215221. doi:10.1289/ehp.5589
Jones D (1998) Organic acids in the rhizosphere - a critical review. Plant Soil 205:25-44. doi:10.1023/a:1004356007312

Keyes SD, Daly KR, Gostling NJ, Jones DL, Talboys P, Pinzer BR, Boardman R, Sinclair I, Marchant A, Roose T (2013) High resolution synchrotron imaging of wheat root hairs growing in soil and image based modelling of phosphate uptake. New Phytol 198:1023-1029. doi:10.1111/Nph. 12294

Laporte MA, Denaix L, Pages L, Sterckeman T, Flenet F, Dauguet S, Nguyen C (2013) Longitudinal variation in cadmium influx in intact first order lateral roots of sunflower (Helianthus annuus. L). Plant Soil 372:581-595. doi:10. 1007/s11104-013-1756-3

Laporte MA, Denaix L, Dauguet S, Nguyen C (2014) Longitudinal variation in cadmium influx in sunflower (Helianthus annuus L.) roots as depending on the growth substrate, root age and root order. Plant Soil 381:235-247. doi:10.1007/s11104-014-2123-8

Laporte M-A, Sterckeman T, Dauguet S, Denaix L, Nguyen C (2015) Variability in cadmium and zinc shoot concentration in 14 cultivars of sunflower (Helianthus annuus L.) as related to metal uptake and partitioning. Environ Exp Bot 109:4553. doi:10.1016/j.envexpbot.2014.07.020

Leblanc J-C, Verger P, Guérin T, Volatier J-L (2004) Etude de l'alimentation totale française. Mycotoxines, minéraux et éléments traces. Institut National Agronomique ParisGrignon, Ministère de l'Agriculture, de l'Alimentation, de la Pêche et des Affaires Rurales, Paris

Li TQ, Liang CF, Han X, Yang XE (2013) Mobilization of cadmium by dissolved organic matter in the rhizosphere of hyperaccumulator Sedum alfredii. Chemosphere 91:970976. doi:10.1016/j.chemosphere.2013.01.100

Lide DR (2004) CRC handbook of chemistry and physics: a ready-reference book of chemical and physical data, 85th edn. CRC Press, Boca Raton

Lin Z, Schneider A, Nguyen C, Sterckeman T (2014) Can ligand addition to soil enhance Cd phytoextraction? A mechanistic model study. Environ Sci Pollut Res 21:12811-12826. doi: 10.1007/s11356-014-3218-8

Lux A, Martinka M, Vaculik M, White PJ (2011) Root responses to cadmium in the rhizosphere: a review. J Exp Bot 62:21-37. doi:10.1093/jxb/erq281

Mesquita ME, Silva J (2002) Preliminary study of $\mathrm{pH}$ effect in the application of Langmuir and Freundlich isotherms to $\mathrm{Cu}-\mathrm{Zn}$ competitive adsorption. Geoderma 106:219-234. doi:10. 1016/s0016-7061(01)00125-2

Metselaar K, De Jong van Lier Q (2011) Scales in single root water uptake models: a review, analysis and synthesis. Eur J Soil Sci 62:657-665

Mullins GL, Sommers LE, Barber SA (1986) Modelling the plant uptake of cadmium and zinc from soils treated with sewage sludge. Soil Sci Soc Am J 50:1245-1250

Nigam R, Srivastava S, Prakash S, Srivastava MM (2001) Cadmium mobilisation and plant availability - the impact of organic acids commonly exuded from roots. Plant Soil 230:107-113. doi:10.1023/a:1004865811529

Nye PH, Marriott FHC (1969) A theoretical study of the distribution of substances around roots resulting from simultaneous diffusion and mass flow. Plant Soil 30:459-473

Panfili F, Schneider A, Vives A, Perrot F, Hubert P, Pellerin S (2009) Cadmium uptake by durum wheat in presence of 
citrate. Plant Soil 316:299-309. doi:10.1007/s11104-0089782-2

Parker DR, Pedler JF (1997) Reevaluating the free-ion activity model of trace metal availability to higher plants. Plant Soil 196:223-228. doi:10.1023/a:1004249923989

PDE Solutions Inc. (2012) A flexible solution system for partial differential equations

Pinheiro JP, Mota AM, Goncalves MLS (1994) Complexation study of humic acids with cadmium(II) and lead(II). Anal Chim Acta 284:525-537. doi:10.1016/0003-2670(94) 85059-3

Ponizovsky AA, Metzler DM, Allen HE, Ackerman AJ (2006) The effect of moisture content on the release of organic matter and copper to soil solutions. Geoderma 135:204 215. doi:10.1016/j.geoderma.2005.12.004

Ptashnyk M, Roose T, Jones DL, Kirk GJD (2011) Enhanced zinc uptake by rice through phytosiderophore secretion: a modelling study. Plant Cell Environ 34:2038-2046. doi:10.1111/j. 1365-3040.2011.02401.x

Redjala T, Sterckeman T, Morel JL (2009) Cadmium uptake by roots: contribution of apoplast and of high- and low-affinity membrane transport systems. Environ Exp Bot 67:235-242. doi:10.1016/j.envexpbot.2009.05.012

RMQS C (2013). INRA, Unité INFOSOL, Orléans, France. http:// www.gissol.fr/

Roose T, Fowler AC, Darrah PR (2001) A mathematical model of plant nutrient uptake. J Math Biol 42:347-360. doi:10.1007/ s002850000075

Saltelli A, Tarantola S, Campolongo F, Ratto M (2004) Sensitivity analysis in practice: A guide to assessing scientific models. Wiley

Sauvé S, Hendershot W, Allen HE (2000a) Solid-solution partitioning of metals in contaminated soils: dependence on $\mathrm{pH}$, total metal burden, and organic matter. Environ Sci Technol 34:1125-1131. doi:10.1021/es9907764

Sauvé S, Norvell WA, McBride M, Hendershot W (2000b) Speciation and complexation of cadmium in extracted soil solutions. Environ Sci Technol 34:291-296. doi:10.1021/ es $990202 z$

Schneider A (2008) An exhange method to investigate the kinetics of Cd complexation in soil solutions. Environ Sci Technol 42:4076-4082. doi:10.1021/es0717820

Schneider A, Nguyen C (2011) Use of an exchange method to estimate the association and dissociation rate constants of cadmium complexes formed with low-molecular-weight organic acids commonly exuded by plant roots. J Environ Qual 40:1857-1862. doi:10.2134/jeq2010.0529

Schneider A, Nguyen C, Denaix L (2009) Estimation of the association and dissociation rate constants of $\mathrm{Cd}$ complexes with various aminopolycarboxylic acids by an exchange method. Environ Chem 6:334-340
Schnepf A, Jones D, Roose T (2011) Modelling nutrient uptake by individual hyphae of arbuscular mycorrhizal fungi: temporal and spatial scales for an experimental design. Bull Math Biol 73:2175-2200. doi:10.1007/s11538-010-9617-1

Schnepf A, Leitner D, Klepsch S (2012) Modeling Phosphorus Uptake by a Growing and Exuding Root System. Vadose Zone J 11. doi: 10.2136/Vzj2012.0001

Seuntjens P, Nowack B, Schulin R (2004) Root-zone modeling of heavy metal uptake and leaching in the presence of organic ligands. Plant Soil 265:61-73. doi:10.1007/s11104-0058470-8

Sterckeman T, Perriguey J, Caël M, Schwartz C, Morel JL (2004) Applying a mechanistic model to cadmium uptake by Zea mays and Thlaspi caerulescens: Consequences for the assessment of the soil quantity and capacity factors. Plant Soil 262: 289-302

Stritsis C, Steingrobe B, Claassen N (2014) Cadmium dynamics in the rhizosphere and $\mathrm{Cd}$ uptake of different plant species evaluated by a mechanistic model. Int J Phytoremediat 16: 1104-1118. doi:10.1080/15226514.2013.821445

Szegedi K, Vetterlein D, Nietfeld H, Jahn R, Neue HU (2008) New tool RhizoMath for modeling coupled transport and speciation in the rhizosphere. Vadose Zone J 7:712-720. doi:10. 2136/Vzj2007.0064

Tinker PB, Nye PH (2000) Solute movement in the rhizosphere. Oxford University Press, New York

Tipping E, Lofts S, Sonke JE (2011) Humic Ion-binding model VII: a revised parameterisation of cation-binding by humic substances. Environ Chem 8:225-235. doi:10.1071/En11016

Tsang DCW, Zhang W, Lo IMC (2007) Modeling cadmium transport in soils using sequential extraction, batch, and miscible displacement experiments. Soil Sci Soc Am J 71:674-681. doi:10.2136/sssaj2006.0299

Tudoreanu L, Phillips CJC (2004) Empirical models of cadmium accumulation in maize, rye grass and soya bean plants. J Sci Food Agric 84:845-852. doi:10.1002/jsfa. 1730

Varney GT, Canny MJ (1993) Rates of water uptake into the mature root system of maize plants. New Phytol 123:775786. doi:10.2307/2557892

Wang DZ, Jiang X, Rao W, He JZ (2009) Kinetics of soil cadmium desorption under simulated acid rain. Ecol Complex 6:432437. doi:10.1016/j.ecocom.2009.03.010

Williams M, Yanai RD (1996) Multi-dimensional sensitivity analysis and ecological implications of a nutrient uptake model. Plant Soil 180:311-324

Yin YJ, Impellitteri CA, You SJ, Allen HE (2002) The importance of organic matter distribution and extract soil : solution ratio on the desorption of heavy metals from soils. Sci Total Environ 287:107-119. doi:10.1016/s0048-9697(01)01000-2

You SJ, Yin YJ, Allen HE (1999) Partitioning of organic matter in soils: effects of $\mathrm{pH}$ and water/soil ratio. Sci Total Environ 227:155-160. doi:10.1016/s0048-9697(99)00024-8 